\title{
DIRECT DESIGN AND ASSESSMENT OF THE LIMIT STATES OF STEEL PLANAR FRAMES USING CSD ADVANCED ANALYSIS
}

\begin{abstract}
A. M. BARSZCZ ${ }^{1}$
This paper is entirely devoted to practical aspects of direct design and assessment of safety and serviceability of steel planar framework using advanced analysis. The development of advanced analysis has been driven by a desire for a more accurate representation of the behaviour of planar framework by considering the beam and spring numerical modelling technique together with plasticity and geometrically nonlinear effects as well as structural imperfections accounted for. The validated 2D version of CSD advanced analysis developed by the author is used in this paper for its practical application towards the resistance and serviceability assessment of existing simple construction framework. This steel braced frame was a subject of technical expertise. The same structure geometry but with different joint detailing is then considered to show how the effect of joint properties may affect the braced frame performance. Results of investigations are presented in the form of frame global response at both the ultimate limit state and the serviceability limit state, and also in the form of member local responses. Conclusions with regard to general design and assessment practice are drawn.
\end{abstract}

Keywords: steel framework, I-section member, class 1 section, braced frame, in-plane CSD advanced analysis, direct design, direct assessment of existing framework

\section{INTRODUCTION}

The term advanced analysis of steel framework is referred hereafter to that named GMNIA in the current Eurocode 3 [1] in which all the important factors influencing the structural performance are accounted for, usually in an approximate way for engineering practice $[2,3]$. When in-plane 2D advanced analysis of planar framework is employed for design purposes [4-9] it has to be ensured

\footnotetext{
${ }^{1}$ PhD., C. Eng., Warsaw University of Technology, Faculty of Civil Engineering, Al. Armii Ludowej 16, 637 Warsaw, Poland, e-mail: a.barszcz@il.pw.edu.pl
} $00-$ 
that the framework behaviour is not governed by out-of-plane buckling of moment resisting members (not governed by lateral-torsional modes of failure). When this is not the case, 2D advanced analysis has to be completed by separate lateral and lateral-torsional buckling resistance checks referred to frame individual beam-columns or substructures. The most unfavourable load factor from those related to either the in-plane limit point on the load-deflection response curve or to the attainment of the out-of-plane buckling resistance of the frame most critical member of substructure, becomes the frame ultimate strength load factor. More complex 3D advanced analysis tends to directly account for combined effects of the flexural-torsional buckling together with gradual development of plastic deformations and members overall and local buckling [10-13]. Since at present, the former advanced analysis can take the joint in-plane semi-rigidity more efficiently into account than the latter one when taking the joint space semi-rigidity into account, it is believed that 2D advanced analysis allows for a more reliable assessment of the ultimate limit states of planar steel framework.

Utilization of advanced methods of analysis in practical design has becoming more and more visible in recent novelizations of steelwork design codes in the Pan-American region [14] and in European Union region [3].

A summary of different approaches to in-plane advanced analysis has been presented in [15] together with the validation of CSD version of advanced analysis developed by the author. This paper presents the author's contribution to the development of direct design and assessment of steel frameworks using CSD advanced analysis being as close as possible to the real behaviour of steel skeletal load bearing systems. The principal purpose of this paper is to present the proposed design-assessment flowchart implementing the in-plane CSD advanced analysis and showing its practical application in detailed investigations of the ultimate and serviceability limit states (ULS and SLS) in modelling of a real simple construction in the form of steel framework. The structure considered was a subject of technical expertise at the Warsaw University of Technology taking into consideration its originally erected version and the modified version in which some structural members had been reinforced.

At the beginning, the application of the CSD advanced analysis is illustrated by investigating the behaviour of a simple Mises truss. The truss is under independent load components, vertical and horizontal. Next the simple construction is considered. Firstly, the originally designed framework is investigated making the assessments of its performance at the ULS and SLS by the analysis carried out in one computational run, according to the proposed two-sequence load history algorithm. Secondly, the same frame geometry is considered taking into account the member reinforcements, and the responses of two above mentioned frames were compared. Finally, the geometry and members properties of the originally erected frame were taken into consideration but with semi-rigid 
and nominally rigid beam-to-column joints Outcomes of the investigations allowed for conclusions to be drawn with regard to the possible scope of practical applications of the developed CSD advanced analysis and the proposed design-assessment flowchart.

\section{PROPOSED DESIGN-ASSESSMENT ALGORITHM BASED ON CSD ADVANCED ANALYSIS}

\subsection{BRIEF SUMMARY OF MODELLING ASPECTS}

The formulation of proposed CSD advanced analysis has been given in [15] and it is not presented hereafter in details. The most important aspects of framework discrete model in reference to structural topology are as follows:

1. Moment resisting members of planar framework are modelled as line super-elements (shortly called hereafter as the line elements) being an assembly of line sub-elements of three degrees of freedom at each end (3 DOFs, one rotational in the framework plane and two translational, in the longitudinal and transverse directions with regard to the member axis) and a rotational spring at each end of the line sub-element. The discretization is made in such a way that the line super-element nodes are placed at the points of intersection of member axis and the neighbouring member physical contour to which the considered element is attached to. From this point to the point of theoretical intersection of connected members there are notionally rigid elements placed (nominally rigid links). When the frame element is subjected only to end moments (no in-span loads), it is divided into at least two line super-elements, usually of an equal length, or an unequal length if it is required upon the design situation. As a result, the minimal discretization mesh of the joint-to-joint frame elements is to represent the frame member by two line moment resisting elements with the possibility of semirigid joint at one end. When there are members with in-span loads in the form of concentrated forces, the member has to be generally divided for more line elements than two, the nodes of which need to be placed at the discrete points of concentrate loads. When there are distributed loads acting alone, or in addition to the previously mentioned ones, the discretization mesh has to be more fine in order to reproduce as close as possible the plastic zone formation within the frame members.

2. Axial force resisting members of planar framework are modelled as equivalent truss members the stiffness of end joints of which are treated as nominally pinned. In particular, the frame bracing subsystem is modelled as an assembly of single line elements of one degree of freedom at each end 
(1 translational DOF in the direction of the member axis). The stiffness reduction and buckling effects on the equivalent truss member behaviour is automatically inherited in the element constitutive model of its force-deformation characteristic.

Investigations presented in [15] have proven that the numerical model based on the application of discretization rules summarized under 1 and 2 above are sufficient for getting the results with degree of accuracy acceptable from the engineering point of view. In solving the nonlinear system of equilibrium equations, the simple incremental method is adopted. In real situations, steel framework is subjected not to a single load component but to a combination of load components that may act independently from each other. The self-weight and execution loads are usually applied during the construction stage. They are gradually increased by adding the permanent load components. As a result, before service stage of the structure, loads acting on the structure are the permanent loads. During the structure service there are a number of possibilities of load combinations the structure may be subjected to in different lifetime intervals. The Eurocode's design philosophy establishes four load combinations to be used in different design situations, namely fundamental, characteristic, frequent and quasi-permanent. The first load combination is used for the ultimate limit state verification (ULS verification), the next two for the serviceability limit state verification (SLS verification) when the rheological effects do not affect the structural performance, and finally the last one when the rheological behaviour needs to be considered (usually not relevant to skeletal steelworks).

The most common design situation is when structural building systems are subjected to quasi-static, repeatable load combinations for which the ULS verification under fundamental load combinations is to be accompanied by the SLS verification under characteristic or frequent load combinations. Advanced analysis in this case has to be performed independently for each load combination from those that are possible to exist during the prescribed period of service. The task is to find the minimal load multiplier $\alpha_{\mathrm{ult}}$ from those obtained in numerical simulations performed for all identified design load combinations $\alpha_{\text {ult,i }}(\mathrm{i}=1,2,3 \ldots, \mathrm{n}$ where $\mathrm{n}$ is the number of realistic and physically possible load combinations). An additional checking has to be performed for the evaluation of the serviceability utilization ratio for the load multiplier $\alpha_{S L S}=1$ with respect to relevant load combinations

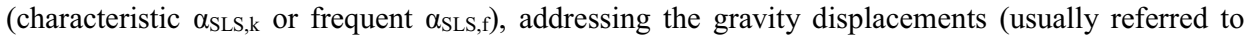
beams) and sway displacements (usually referred to the structure drift or storey drift of columns). The necessity to perform simulations for two types of load combinations:

1. Fundamental and characteristic for the identification of $\alpha_{\mathrm{ult}}$ and the serviceability load effects under $\alpha_{\mathrm{SLS}, \mathrm{k}}=1$. 
2. Fundamental and frequent for the identifications $\alpha_{\text {ult }}$ and the serviceability load effects under $\left.\alpha_{\mathrm{SLS}, \mathrm{f}}=1\right)$. Each type of the load combinations involved requires simulations for several different load combinations composed of a number of load components in the considered combinations what makes the design process rather complicated.

In the proposed direct design procedure, following attributes are designated for with regard to the solving procedure:

1. The nonlinearity of the load-displacement response investigated requires in ULS to perform simulations for a number of fundamental load combinations with the loads $F_{d, U L S, i}(i=1,2, \ldots, n)$. The incrementation process for a certain load combination "i" is performed, the advanced analysis with a single load history sequence, up to the load level (i.e. $\alpha_{U L S, i}=1$ ), and alternatively being continued in order to identify the load multiplier corresponding to the limit point on the equilibrium path (for which $\alpha_{\text {ult,i }} \geq 1$ predicts the safety margin in the ULS). After performing advanced analysis in a loop and identifying all the limit point load factors $\alpha_{\mathrm{ult}, \mathrm{i}}(\mathrm{i}=1,2, \ldots, \mathrm{n})$ for all the load combinations, an estimation of the collapse limit state and the mechanism of failure may then be predicted for the load factor $\alpha_{\text {ult }}=\min \alpha_{\text {ult,i. }}$. Furthermore, the SLS calculations require separate simulations for generally the same (or similar) number of load combinations as considered in the ULS but with use of relevant proportion between the load components $\mathrm{F}_{\mathrm{d}, \mathrm{SLS}, \mathrm{i}}$ of each "i" serviceability load combinations (characteristic or frequent). Noticeably, the proportion between load components in $\mathrm{F}_{\mathrm{d}, \mathrm{SLS}, \mathrm{i}}$ design load combinations is different from $\mathrm{F}_{\mathrm{d}, \mathrm{ULS}, \mathrm{i}}$ in the ULS design load combinations.

2. In order to simplify the design procedure, it is proposed that the load history is of a sequential two stage one, carried out automatically within one simulation run for each load combination specified. In the first stage, up to the load factor $\alpha_{S L S, i}=1$ of the SLS load combination (characteristic or frequent), the load incrementation is applied keeping the relevant proportion between the load components. The field of nodal displacements corresponding to this load level is utilized for checking the SLS criteria. The second stage of load-displacement response analysis is performed for the notional load components $F_{\text {comp,i }}$ being for each load combination the difference between its design fundamental and serviceability values, i.e. $\mathrm{F}_{\mathrm{comp}, \mathrm{i}}=\mathrm{F}_{\mathrm{d}, \mathrm{ULS}, \mathrm{i}}-\mathrm{F}_{\mathrm{d}, \mathrm{SLS}, \mathrm{i}}$. The incrementation process is continued up to the design load level (i.e. $\alpha_{U L S, i}=1$ ).

3. The most important aspect of adopted solving procedure is to keep the increments as small as possible in order to avoid an excessive drift of the frame load-deflection characteristic and the limit point estimate from those predicted on the basis of incremental-iterative solvers. The practical advice is to initiate analysis with the increments $\Delta \mathrm{F}_{\mathrm{d}, \mathrm{ULS}, \mathrm{I}}, \Delta \mathrm{F}_{\mathrm{d}, \mathrm{SLS}, \mathrm{I}}$ and $\Delta \mathrm{F}_{\text {comp }}$ being of $1 / 100$ of the actual design load combination considered. 


\subsection{PROPOSED DIRECT DESIGN-ASSESSMENT PROCEDURE}

Let us consider a selected load combination "i". For convenience of writings, the index "i" is dropped off hereafter. In order to facilitate direct design-assessment procedure, analysis is based on simulations carried out for the sequential, two stage load incrementation history. In the first load incrementation stage, the reference load level corresponds to that of $\mathrm{F}_{\mathrm{d}, \mathrm{SLS}}$ for the SLS verification

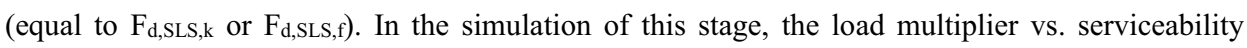
utilization ratio characteristics are presented for checking the serviceability utilization ratio being the greatest from the maximum gravity displacement $\delta_{\text {ver,max }}$ and the sway displacement $\delta_{\text {hor,max }}$ divided by their limiting values (i.e. $\delta_{\mathrm{ver}, \max } / \delta_{\mathrm{ver}, \text { lim }}$ or $\delta_{\mathrm{hor}, \max } / \delta_{\mathrm{hor}, \text { lim, }}$, respectively). At the end of this stage, the SLS verification is positive when for the load multiplier $\alpha_{\mathrm{SLS}}=\Sigma \Delta \mathrm{F}_{\mathrm{d}, \mathrm{SLS}} / \mathrm{F}_{\mathrm{d}, \mathrm{SLS}}=1$ the serviceability utilization factors are less than unity. The simulation is then continued but the load incrementation algorithm is different from that of the first stage. The reference load level is $F_{d, U L S}$ for the ULS verification so that the load incrementation refers to the complement of the design loads $\mathrm{F}_{\text {comp }}=\mathrm{F}_{\mathrm{d}, \mathrm{ULS}}-$ $\mathrm{F}_{\mathrm{d} \text {,SLS }}$ and the load multiplier is calculated as $\alpha_{\mathrm{d}}=\mathrm{F}_{\mathrm{d}, \mathrm{SLS}} / \mathrm{F}_{\mathrm{d}, \mathrm{ULS}}+\alpha_{\text {comp }} \cdot \mathrm{F}_{\text {comp }} / \mathrm{F}_{\mathrm{d} \text {,ULS }}$ where $\alpha_{\text {comp }}=$

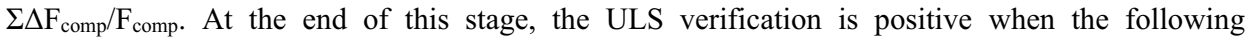
relationship is met:

$$
\alpha_{\mathrm{d}}=\mathrm{F}_{\mathrm{d}, \mathrm{SLS}} / \mathrm{F}_{\mathrm{d}, \mathrm{ULS}}+\alpha_{\mathrm{comp}}\left(\mathrm{F}_{\mathrm{comp}} / \mathrm{F}_{\mathrm{d}, \mathrm{ULS}}\right) / \gamma_{\mathrm{M} 1}>1.0
$$

The partial resistance factor $\gamma_{\mathrm{M} 1}=1.0$ is adopted as it has been in [2]. Therefore, when for the load multiplier $\alpha_{\text {comp }}=1$ (i.e. when $\alpha_{d}=F_{d} / F_{d, U L S}=1$ ), the structure does not fail when the structure stiffness matrix is still nonsingular and the structure is able to take up increased loads. When the partial factor is postulated to be greater than unity, the analysis has to be progressed up the attainment the load level on the equilibrium path that corresponds to the load multiplier $\alpha_{\text {ult }}$ equal to $\gamma_{\mathrm{M} 1}$. The positive ULS verification requires in this case that the simulated load factor $\alpha_{\text {ult }}$ must be greater than, or at least equal to the value postulated for the partial resistance factor $\gamma_{\mathrm{M} 1}$.

The flowchart of two main verification paths using advanced analysis is presented in Fig 1. There are two ways of possible design-assessment strategy. The single sequence path is used only for the ULS verification and the assessment of the safety margin of existing structures. The double sequence path is used for design of new load bearing structural systems in which one analysis run is performed for the verification of two limit states, namely for the SLS verification at the first stage of analysis and then for the ULS verification. 


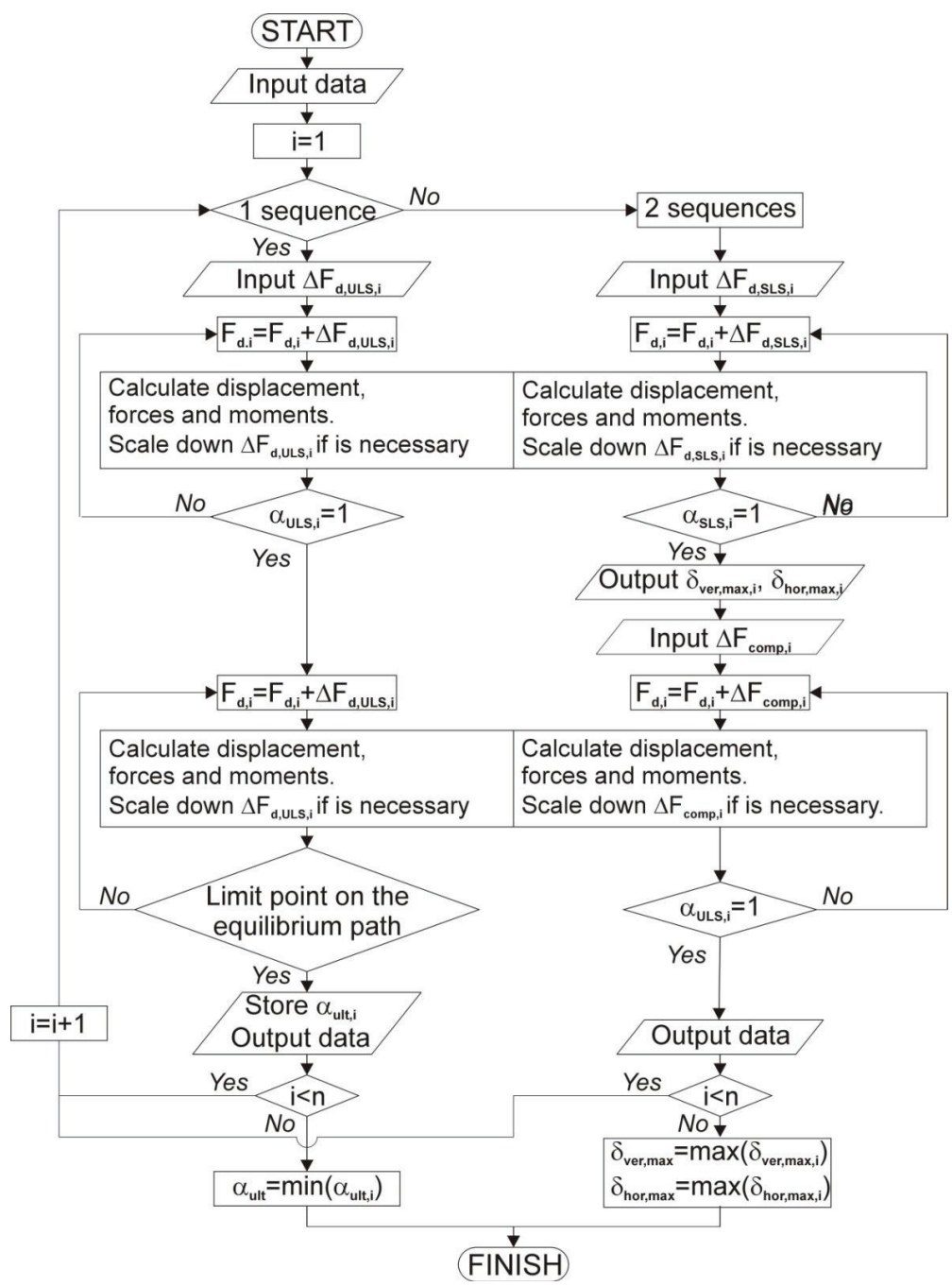

Fig. 1 Flow chart of structural assessment paths for selected load combinations

\section{ILLUSTRATIVE EXAMPLE OF NONLINEAR BUCKLING ANALYSIS OF MISES TRUSS}

Let us consider the Mises truss sensitive to the so-called elastic snap-through buckling and requiring to take into consideration the influence of member prebuckling displacements on the truss buckling state. The truss was investigated in [16] for study the effect of truss member imperfections and joint 
connection types on the truss ultimate limit state. One of the truss initial configurations is considered hereafter but with different loading conditions in order to show the implementation of proposed limit states assessment algorithm presented in subsection 2.2. The example shows the difference between modelling of the truss structure using classical refined plastic hinge advanced method of analysis (identified by RPH-CRC and RPH-LRFD, referred respectively to CRC and LRFD buckling curves in [17]) and the proposed continuous stiffness degradation method of analysis (identified by CSD-W and CSD-B, respectively for welded and bolted angles as in [18]). The difference between the truss member behaviour yields directly from the truss member degradation function adopted. Fig. 2 illustrates the differences (note that tension is associated with the positive value of stress and strain).
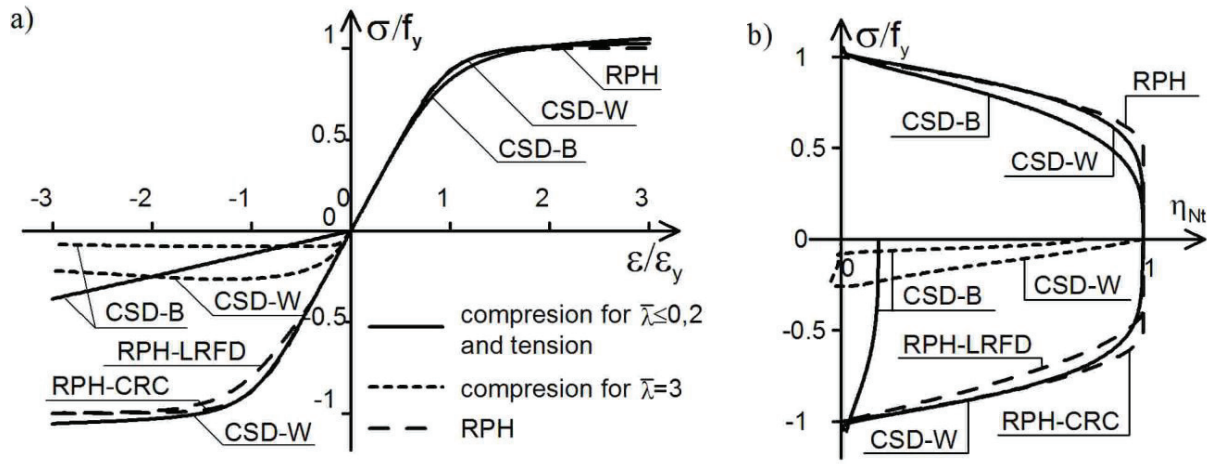

Fig. 2. Illustration of stiffness degradation function $\eta_{\mathrm{N}}$; a) Hypothetical stress-strain relationship; b) Stiffness degradation function in terms of dimensionless stress.

It is visible that in the case of member being under tension all the approaches practically coincide. Contrarily, in the case of member being under compression the approaches diverge. The RPH curves are applicable regardless the member slenderness but provided that they are used only up to the level of the slenderness dependent buckling resistance $N_{b}=\sigma_{b} A\left(\sigma_{b}\right.$ is the buckling stress and $A-$ the member cross sectional area). Above this level, the buckling stress $\sigma_{b}$ is kept constant for the increased strain $\varepsilon$, approximating from above the member real postbuckling behaviour. For stocky members, the RPH curves are therefore valid up to the squash load level $\left(\mathrm{N}_{b}=\mathrm{N}_{\mathrm{pl}}=\mathrm{Af}_{\mathrm{y}}\right.$ were $\mathrm{f}_{\mathrm{y}}$ is the steel yield stress) and in this case the RPH curves practically coincide with that of CSD-W. For slender members, both CSD-W and CSD-B curves differ significantly from those of RPH (both RPH-LRFD and RPH$\mathrm{CRC}$ ) since both CSD curves represent the pre- and post-limit member behavior. The RPH curves for 
compression need to be considered only up to the buckling resistance level while for tension they are valid up to the section yielding.

The truss geometry and loading is shown in Fig. 3a. Analysis was carried out for the truss consisting of two nominally pinned members (angle L60x60x5) the joint arrangements of which are shown in Fig. 3b: angle leg-to-gusset-plate joint with use of bolts (symbol B used) and angle fillet welded forklike joint (symbol $\mathrm{W}$ used). The length of truss members marked as 1 and 2 is equal to $1000 \mathrm{~mm}$ and $1500 \mathrm{~mm}$ for both versions of connections ( $\mathrm{B}$ and $\mathrm{W}$ ). The adopted lengths correspond to the member relative slenderness ratio $\bar{\lambda}$ of 1,0 and 1,5 ; respectively.

a)

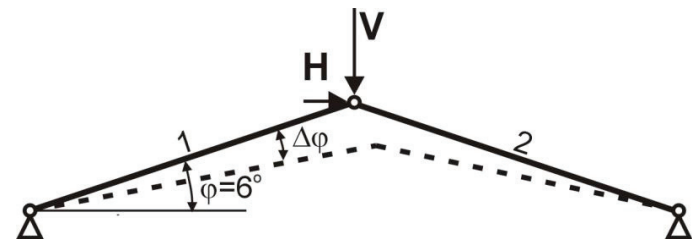

b)
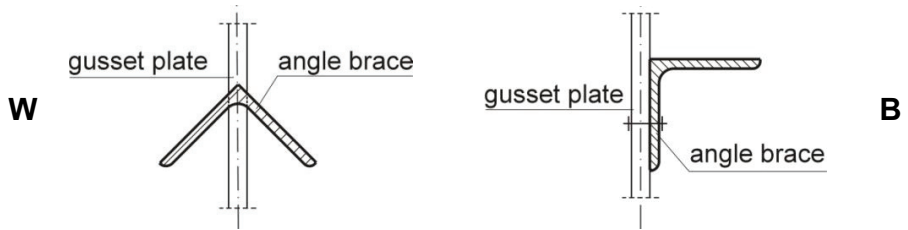

Fig. 3. Mises truss considered: a) geometry and loading, b) truss elements and their connection with gusset plates

\subsection{ASSESSMENT OF THE TRUSS BEHAVIOR UNDER LOADS ACTING INDEPENDENTLY}

Let us first consider the truss with a single vertical load V. The results obtained analytically for the ideally elastic truss of perfect geometry (named Mises truss) were compared with those obtained numerically for the imperfect truss member model [18]. Numerical results correspond to RPH and CSD advanced analyses. Fig. 4 shows the results for two different lengths of the truss members. The load V imposes compression in the truss members. The Mises truss elastic limit load of snap-though buckling for its perfect model is equal to $\mathrm{V}_{\mathrm{el}}=54 \mathrm{kN}$. The attainment of the member buckling resistance level is associated with the ultimate state of the truss. The force redistribution effect cannot be activated in case of the Mises truss.

The following observations can be drawn:

1. Both RPH-CRC and RPH-LRFD approaches give practically the same truss ultimate load and leading to practically the same load vs. member rotation curves coinciding with that of obtained analytically for the perfect elastic truss, despite that there is a visible difference between the RPH 
stiffness degradation values for RPH-CRC and RPH-LRFD. The differences in the RPH stiffness degradation values are noted for the truss consisted of less slender members. For the truss of longer members, there is no difference in the RPH stiffness reduction factors since the range of behavior is within the limit recognized in the RPH approaches as being elastic (therefore the stiffness reduction factor is equal to unity).

2. All the V- $\Delta \varphi$ relationships are smooth, even for both RPH-CRC and RPH-LRFD, since in the said approaches to advanced analysis the truss ultimate load is reached before the member force reaches the member buckling resistance.

a)
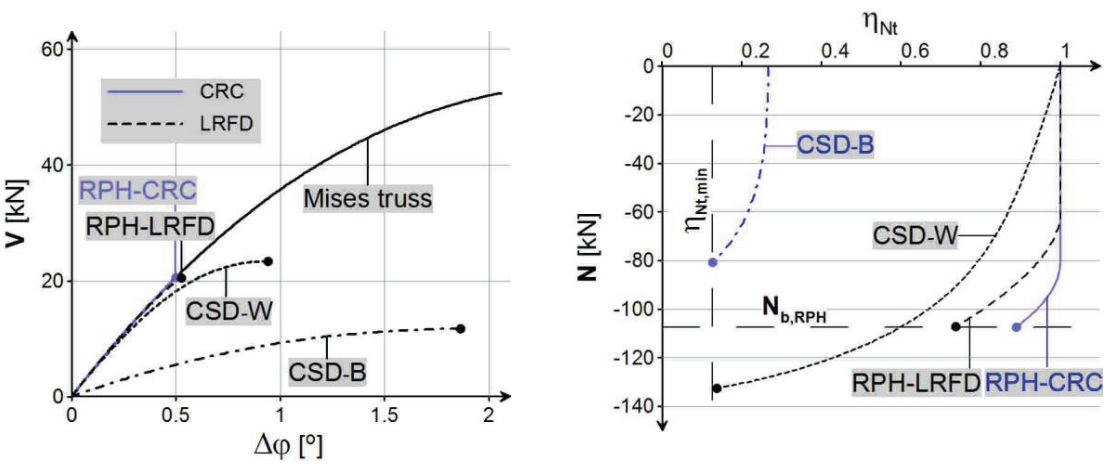

b)
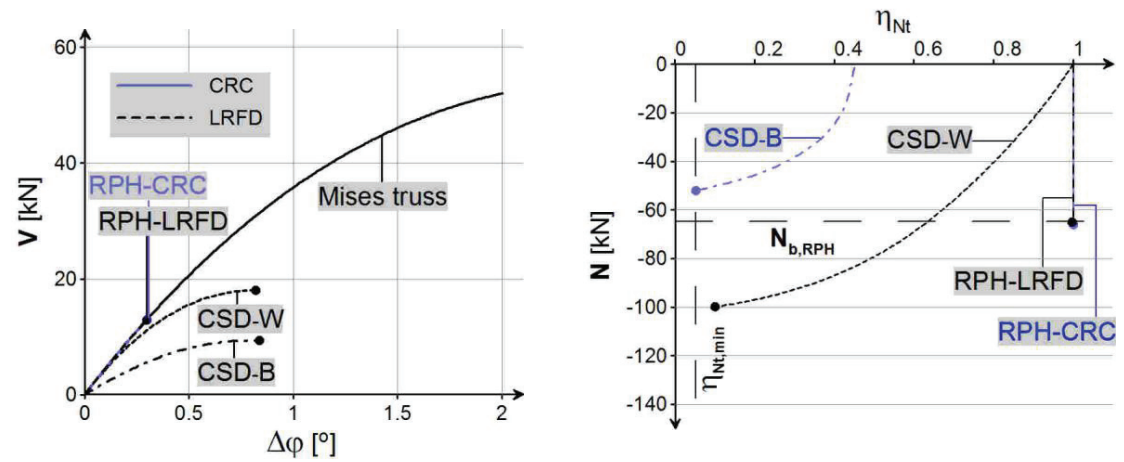

Fig. 4. Vertical load vs. the member rotation curves and axial force vs the stiffness degradation factor curves for the adopted truss member lengths; a) $\mathrm{L}=1000 \mathrm{~mm}, \mathrm{~b}$ ) $\mathrm{L}=1500 \mathrm{~mm}$

3. In the cases of both CSD-W and CSD-B approaches both the limit loads Fult and the presented curves are different from those of RPH approaches.

4. The ultimate load corresponding to CSD-W is higher than that for CSD-B for which the stiffness reduction is faster than that for the CSD-W approach. 
5. The RPH ultimate load is always lower than that of the CSD-W while higher than that of CSD-B. The similar trend is observed for the member axial force relationships.

6. The CSD ultimate loads are reached when the stiffness reduction factors of both compression members are less than $\eta_{\mathrm{Nt} \text {,min }}=0,1$ (at which the buckling resistance is being approached). In the compression post-limit range, the member stiffness becomes of negative value and there is no room for any further load increase to be withstand by the truss.

The similar analysis was carried out for the horizontal force $\mathrm{H}$ without the vertical force V. In this case, one truss member is from the beginning under compression while the other one is under tension. The truss under such a loading condition is expected to behave differently than that being under the vertical force only. The results are presented in Fig. 5. The observations are as follows:

1. The ultimate load $\mathrm{H}_{\text {ult }}$ for CSD-W and RPH-CRS is practically the same $(268 \mathrm{kN})$ for the shorter length of the truss members. The ultimate load evaluated using RPH-LRFD is slightly lower while CSD-B is the lowest for the same member length.

2. For the longer members length, the tendency in the ultimate load attainment is a bit different. The order from the highest ultimate load is here from RPH-CRC down to CSD-W, and further down to RPH-LRFD, and finally down to CSD-B. It is obvious that for longer truss members the highest ultimate load corresponds to RPH-CRC (for less slender members the CSD-W may be the highest). 3. Since the ultimate load for RPH-CRC and RPH-LRFD is being reached in the post-limit range of the truss compression member behavior, and the above stated advanced methods of analysis cannot trace the effect of member stiffness softening, the truss $\mathrm{H}-\Delta \varphi$ relationships exhibit a large increase of the tension member rotation when the buckling resistance is reached in the compression member. This results from the fact that after buckling of the compression member, the total increase of the applied load has to be taken up by the tension member since the force in compression member stays of the constant value equal to the buckling resistance (the member stiffness remains equal to zero). 4. The truss behaviour modeled through RPH-CRC and RPH-LRFD approaches for both member lengths is of a similar nature. In both cases, the ultimate state is associated with large inelastic elongation of the tension member. The deformation of the truss with the longer member length is larger at the ultimate state than the deformation of the truss with the shorter member length. It is well understood because full yielding of the tension member is associated with its larger elongation.

5. The truss behaviour modeled through CSD approach is more smooth in course of progressive stiffness degradation of both compression and tension members. The ultimate load is reached in the post-limit behavior of the compression member when its negative stiffness cannot be balanced by the reduced positive stiffness of the tension member. 
a)
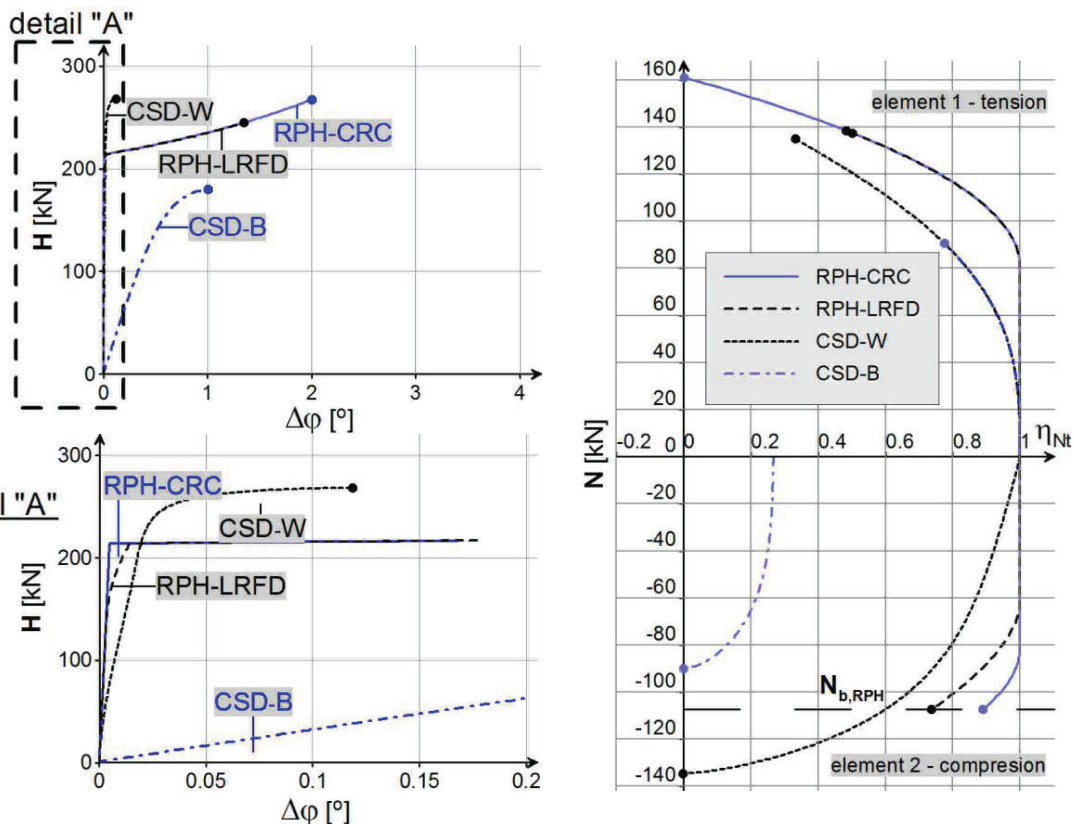

b)
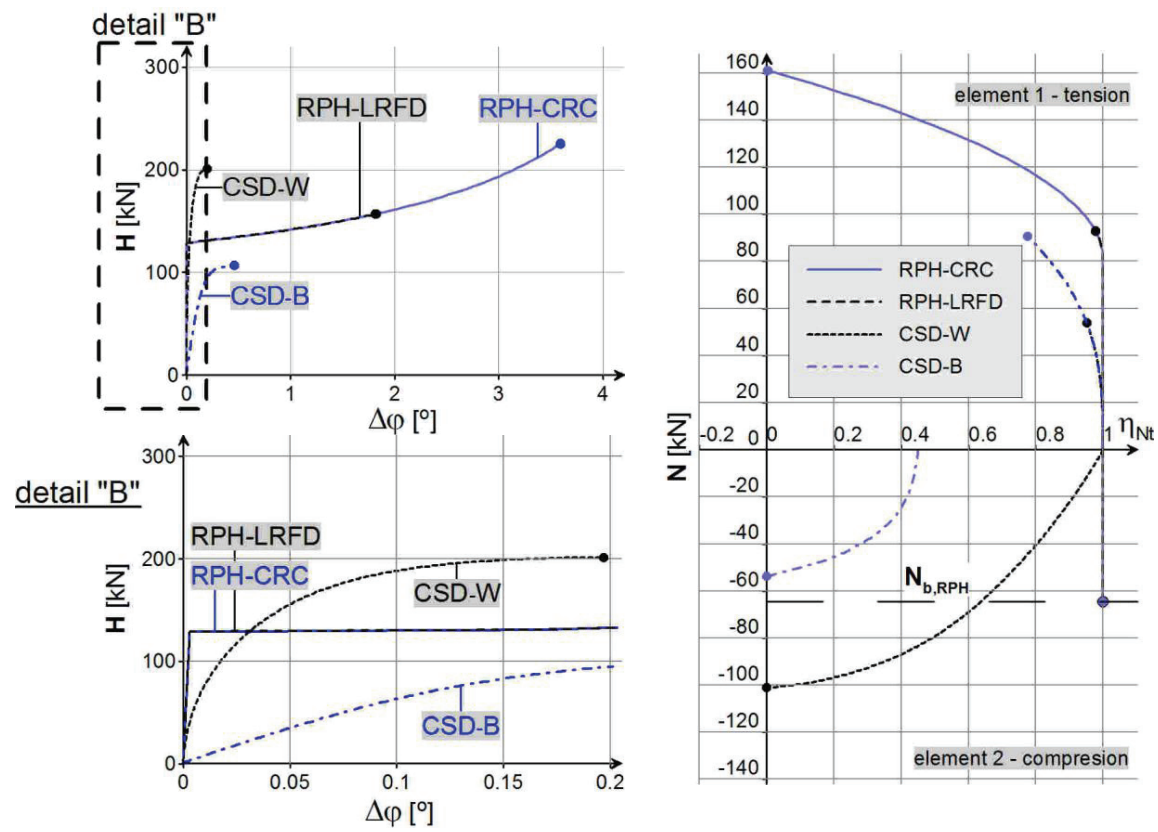

Fig. 5. Horizontal load vs. the member rotation curves and axial force vs the stiffness degradation factor curves for the adopted truss member lengths; a) $\mathrm{L}=1000 \mathrm{~mm}$, b) $\mathrm{L}=1500 \mathrm{~mm}$ 


\subsection{ASSESSMENT OF THE TRUSS BEHAVIOR UNDER TWO LOADS ACTING TOGETHER}

Let us consider the loads $\mathrm{V}$ and $\mathrm{H}$ acting together and increasing not necessary in the proportional manner. Advanced analysis is carried out for the forces $\mathrm{V}$ and $\mathrm{H}$ incremented proportionally (according to a single sequence) or in a non-proportional manner (according to a double sequence, incrementation of forces $\mathrm{V}$ and $\mathrm{H}$ is done one after another). Only the CSD-W approach is used and the truss with members length of $\mathrm{L}=1500 \mathrm{~mm}$ is considered. The vertical force was assumed $\mathrm{V}_{\max }=$ $15,3 \mathrm{kN}$ and the horizontal force $\mathrm{H}=0,15 \mathrm{~V}$. In the single sequence loading history, the vertical load $\mathrm{V}$ and the horizontal one $\mathrm{H}$ are incremented proportionally. In the double sequence loading history, in the first stage the load $0,85 \mathrm{~V}$ is applied. In the second stage, there is the proportional increase of the vertical complementary load $\Delta \mathrm{F}=0,15 \mathrm{~V}$ and the horizontal force $\mathrm{H}$.

It is obvious that levels corresponding to the ultimate load values calculated for the one-sequence loading condition may not the same as those obtained for the two-sequence loading cases. The comparison between one-sequence loading history ( $\mathrm{V}$ and $\mathrm{H}$ increasing proportionally) and twosequence loading history (first $0,85 \mathrm{~V}$ and then $0,15 \mathrm{~V}$ and $\mathrm{H}$ increasing proportionally) is presented in Fig. 6. The following conclusions can be drawn:

1. The load displacement curves of the vertical force vs. the rotation of the truss member 1 , are practically the same for two considered load sequences. The double sequence history results in a slight reduction of $\mathrm{V}_{\max }$ that is accompanied but the substantially higher value of $\mathrm{H}_{\max }$ force.

2. The difference is observed for the curve of the horizontal force vs. rotation of the truss member. In the one sequence load case, the vertical force increases in the same way as the horizontal force so that the maximum horizontal force $\mathrm{H}_{\max }$ at the ultimate state is of the lower value than in case of the two sequence loading conditions. In the two sequence loading conditions, the load increment $\Delta \mathrm{H}$ reduces the compressive force existing in the member 1 after the first load sequence and increases the compressive force in the member 2. A higher value of the force $\mathrm{H}_{\max }$ is therefore require for the truss ultimate limit state to be attained.

The other comparison is between the results of the analysis dealing with one-sequence $\mathrm{V}$ and $\mathrm{H}$ loads and with the two-sequence $\mathrm{V}$ and $\mathrm{H}$ loads for which the high value of the horizontal load $\mathrm{H}$ in reference to the vertical load $\mathrm{V}$ is adopted. The case of $\mathrm{V}=\mathrm{H}=15,3 \mathrm{kN}$ is considered and the results are presented in Fig. 7. The following conclusions can be drawn:

1. The two sequence loading history leads to the lower value of the maximum vertical load $\mathrm{V}_{\max }$ and the higher values of the horizontal load $\mathrm{H}_{\max }$ at the ultimate limit state than those corresponding to the one sequence loading history. 
a)
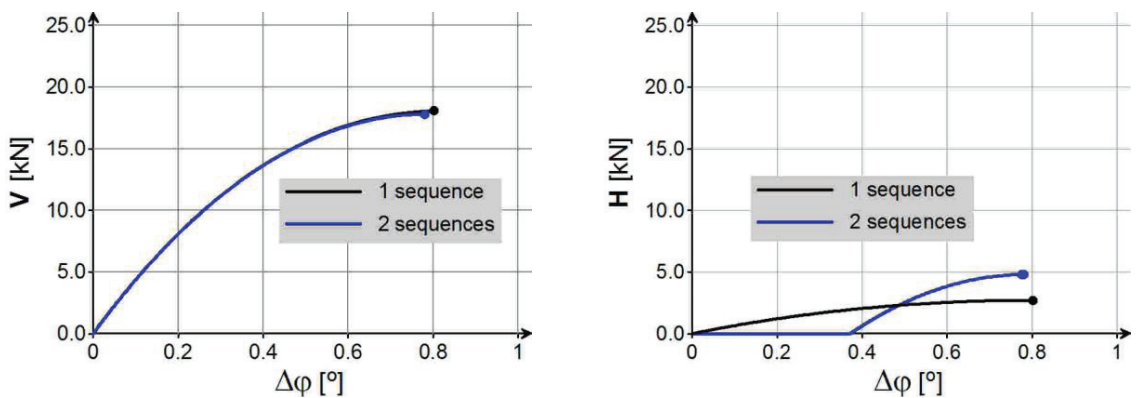

b)
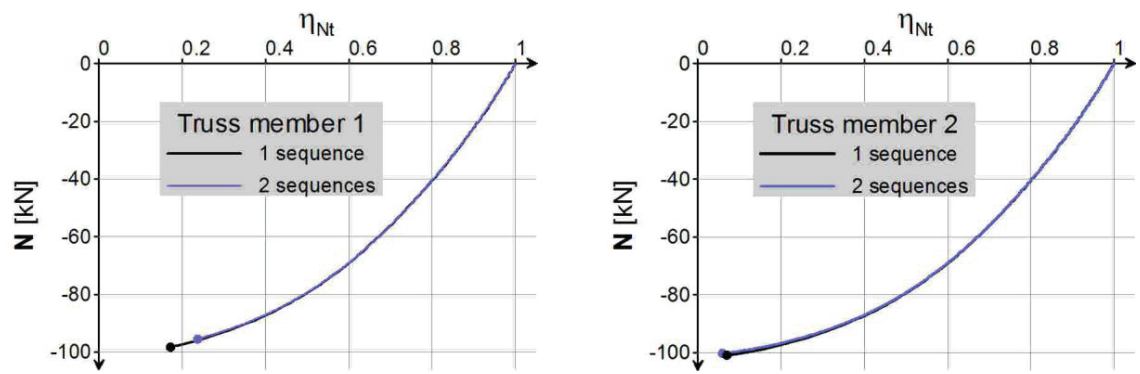

Fig. 6 Numerical results in case of the low horizontal force: a) load-member 1 rotation curves, b) stiffness degradation factor $\eta_{\mathrm{Nt}}$

a)

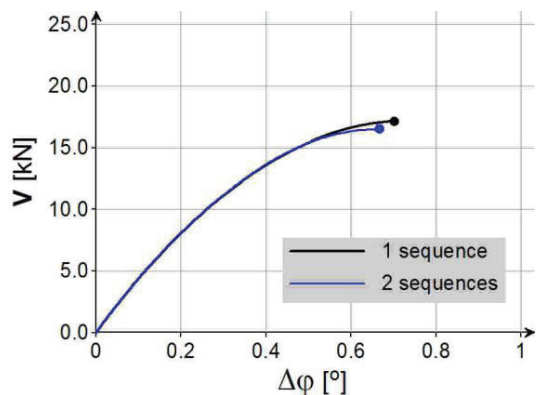

b)

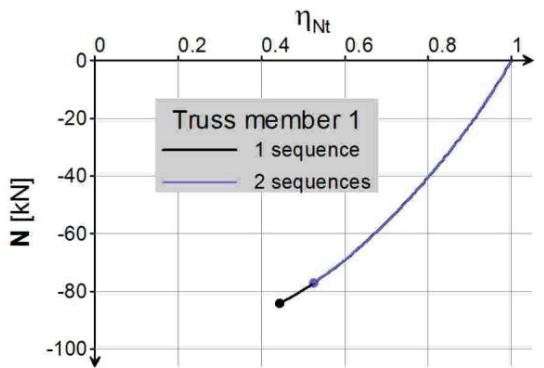

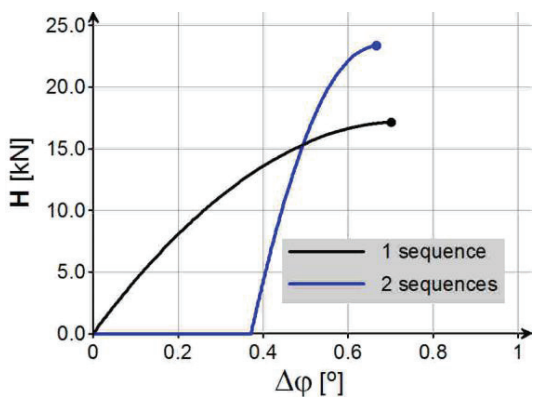

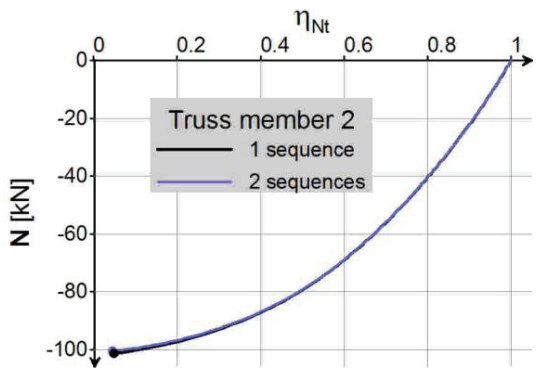

Fig. 7 Numerical results in case of the high horizontal force: a) load-member 1 rotation curves, b) stiffness degradation factor $\eta_{\mathrm{Nt}}$ 
2. The load-member 1-rotation curves $\mathrm{V}-\Delta \varphi$ and $\mathrm{H}-\Delta \varphi$ are of the smooth shape. The reduction of the load multiplier is observed for both the single and double sequence history. The reduction of $\mathrm{V}_{\max }$ in case of higher $\mathrm{H}$ force is a bit greater for the double sequence loading history but it is associated with a more visible increase of $\mathrm{H}_{\max }$.

\section{ASSESSMENT OF LIMIT STATES OF REAL FRAMEWORK}

\subsection{DESCRIPTION OF ORIGINAL FRAME}

Fig. 8 shows the simple construction, referred hereafter to "Frame A", that has been an object of expertise carried out at the Warsaw University of Technology. Frame beams made of I-sections were jointed without the moment transfer onto the column made of $\mathrm{H}$-sections. The structure resistance to wind loads and to sway instability is provided by a vertical truss bracing. Truss members were rolled angle sections. The light gray color refers to the secondary part of the structure omitted in the frame model for advanced CSD analysis. It has however to be notified that the loads collected from of this part of the structural system are transferred onto the main frame system and considered in the present study.

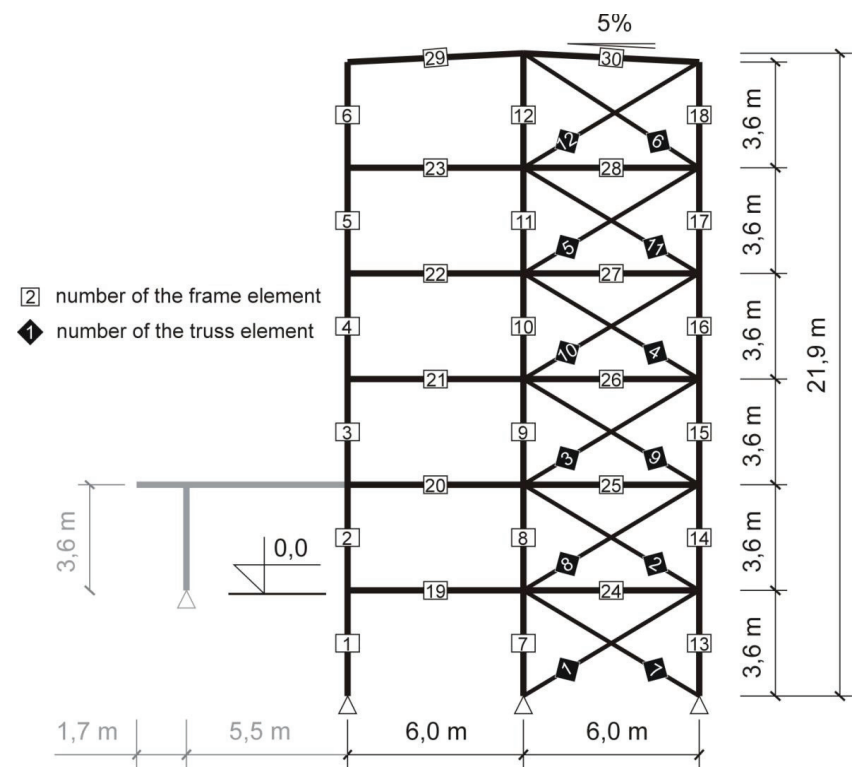

Fig. 8. Simple construction considered for the limit states calculations 
Two case studies of the framework limit states are referred to. Frame sections and joint details of originally designed steelwork were considered first (CS1: Case Study 1). Sections of the original load bearing system were next reinforced during the first stage of frame service in order to fulfill the requirements referred to design loads yielding from a new function of the building as well as from the updated verification criteria introduced in amended design codes. The framework with modified sections was subjected to the assessment for a need of additional reinforcement as a result of the loading condition change in view of the new functionality prescription (CS2: Case Study 2). Both case studies are based on the actual loads calculated according to Eurocodes [19-22]. CS1 deals with a very detailed consideration of all the assessment aspects while CS2 is presented to show only the effect of member reinforcement on the framework ultimate states.

\subsection{MODELLING ASPECTS OF FRAME A}

The sections used for the original structure are shown in Fig. 9 together with respective steel grades, and considered in modelling for the purpose of present study. Roof beams were made of rolled Isections while floor beams and columns were made of welded double-tee plate girders (symbol I is used for narrow flange and $\mathrm{H}$ - for wide flange sections, followed by section dimensions $h \times t_{w} \times b \times t_{f}$ where $h$ - cross section depth, $t_{w}$ - web plate thickness, $b$ - cross section width, $t_{f}-$ flange plate thickness). The floor beam section proportion $\mathrm{b} / \mathrm{h}$ was chosen to resist monoaxial bending about stronger section axis while columns for compression accompanied by monoaxial bending about the same section axis.

The frame beam-to-column and brace-to-column joint details are shown in Fig. 10. Beam-to-column joints shown in Fig. 10 a) are regarded as pins since they fulfil the requirement of Eurocode 3, Part 1-8 [23] for nominally pinned joints. The truss bracing is also considered as nominally pinned to the frame columns as presented in Fig. $10 \mathrm{~b}$ ).

The framework is modelled as an assembly of two subsystems. The framed subsystem (transferring predominantly gravity loads) consists of rigidly connected moment resisting vertical line elements, representing the continuous beam-columns (with the base joints pinned) and moment resisting horizontal line elements, representing the beams with nominally pinned joints between the beams and beam-columns. The truss bracing subsystem (transferring predominantly wind load and ensuring the sway stability) consists of axial force resisting line elements, nominally pinned at both ends to the framed substructure. Brace members are treated from the beginning as imperfect with a continuous stiffness degradation dependent upon the detail of the connection between its angle section and the gusset plate (see Fig. 3b). 
a) I $400 \times 6 \times 180 \times 16$ S355

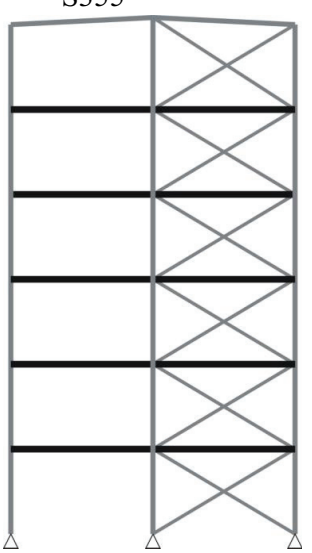

e) $\mathrm{H} 200 \times 12 \times 200 \times 18$ S235

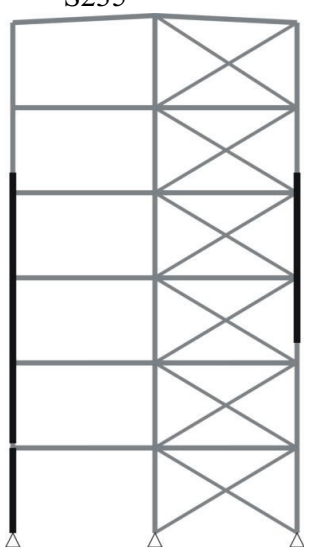

f)
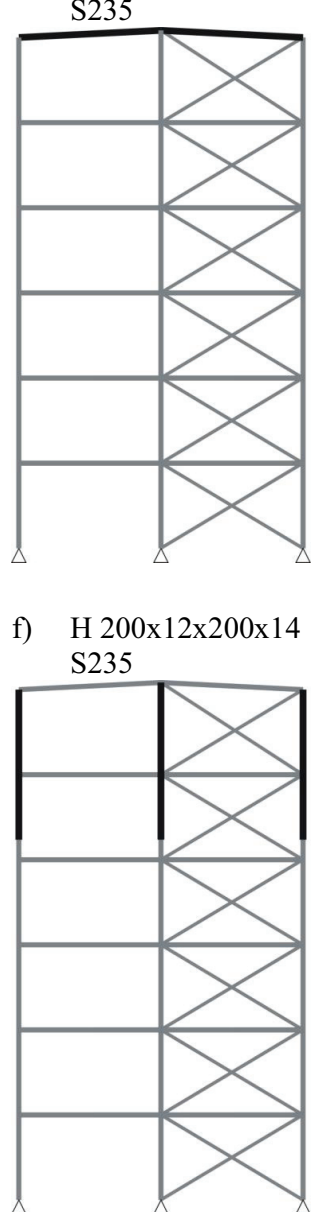

$\triangle$

g) L $120 \times 80 \times 10$ c) $\mathrm{H} 200 \times 18 \times 200 \times 34$ S235 S235

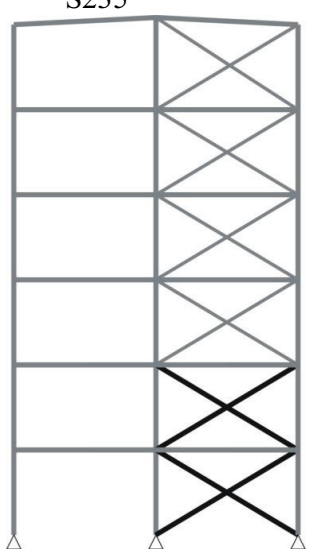

d) $\mathrm{H} 200 \times 18 \times 200 \times 26$ $\mathrm{S} 235$
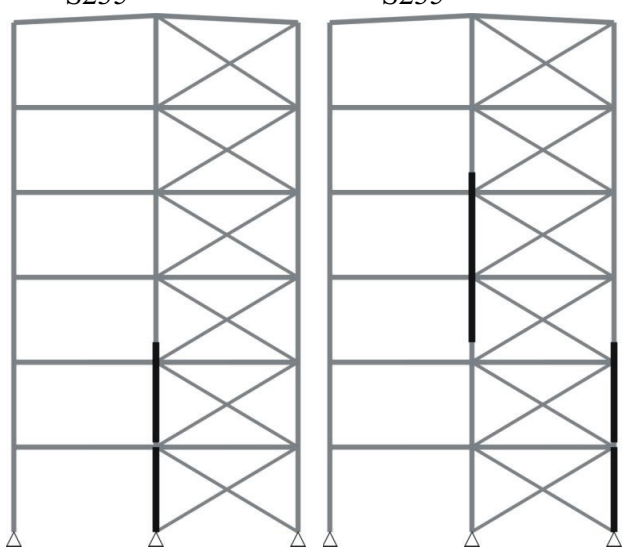

h) L $80 \times 80 \times 10$ $\mathrm{S} 235$

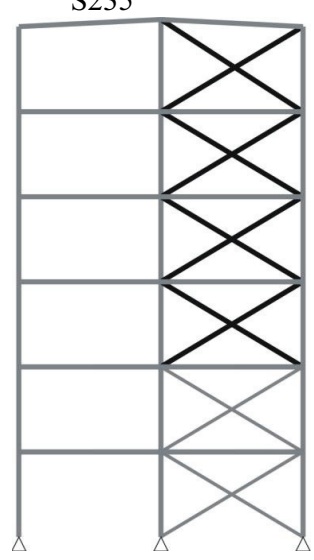

Fig. 9 Sections of frame elements.

a)

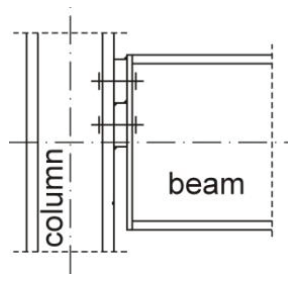

b)

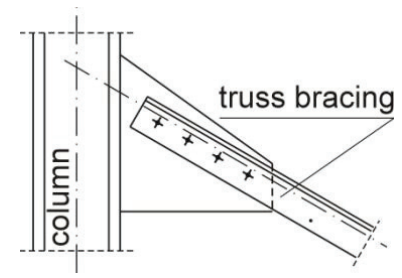

Fig. 10 The frame joint details; a) beam-to-column joint, b) truss bracing-to-column connection 


\subsection{LOADING AND LOAD COMBINATIONS}

The independent load components considered are the permanent loads $\mathrm{G}$ and variable loads: imposed floor loads Q, roof climatic snow loads S and finally the climatic wind loads W. The load combinations considered in CSD analysis are presented in Table 1. The ultimate limit state verification requires the design fundamental load combinations while the serviceability limit states may require one from three design load combinations, namely characteristic, frequent or quasipermanent, in relations to the deformation or vibration control requirements. Each ULS combination is referred to the corresponding SLS combination.

Table. 1 Load combinations

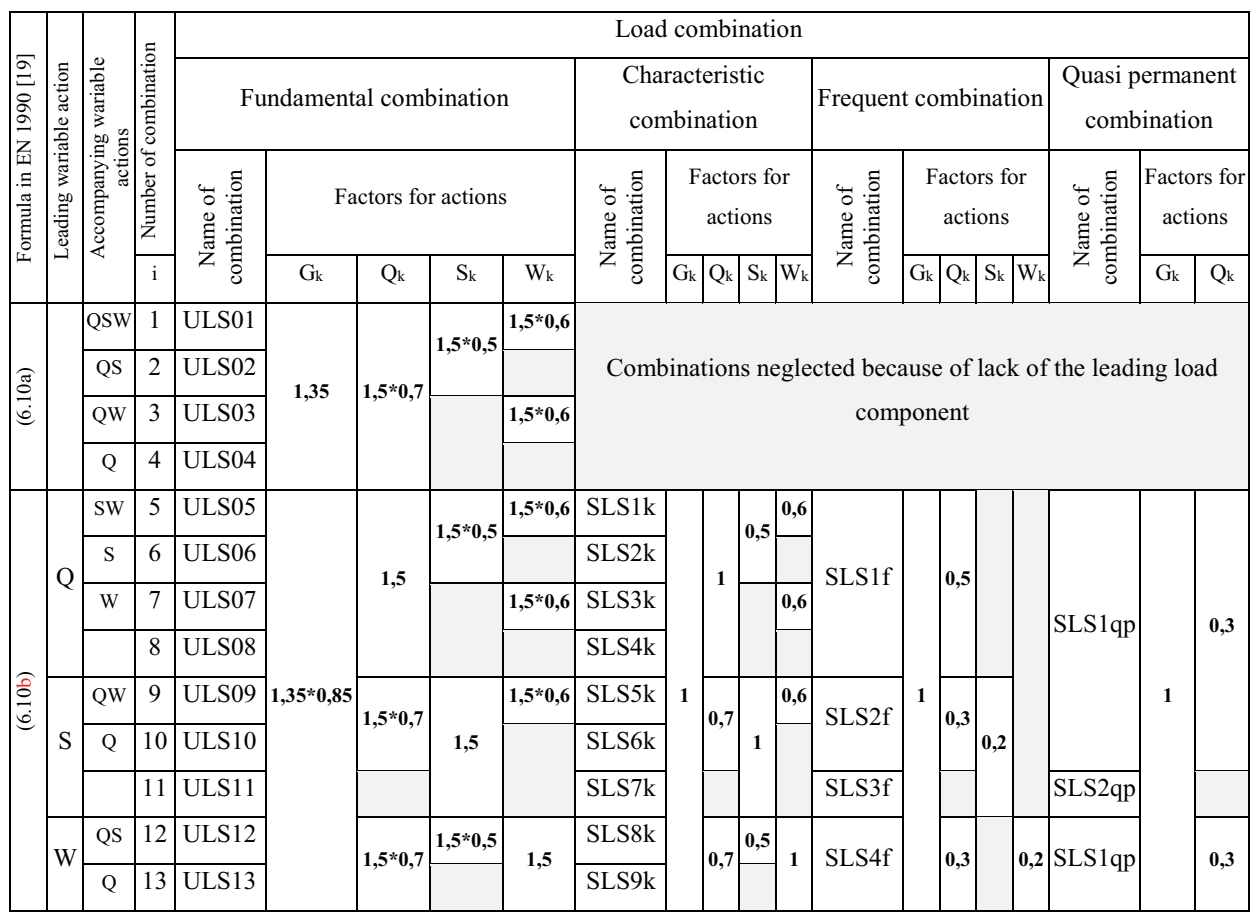

\subsection{NUMERICAL RESULTS OF FRAME A-CS1}

The advanced CSD analysis was performed for all the load combinations specified in Table 1 and for the three classes of the limit states corresponding to design fundamental load combinations for ULS, and design characteristic and frequent load combinations for SLS (with the assumptions that all the 
load components are being increased proportionally to a load parameter $\left.\alpha_{\mathrm{Fd}}\right)$. The results referred to critical load combinations for which $\mathrm{i}=6,11 \mathrm{i} 12$ in Table 2 ( $\mathbf{K}$ is the braced frame stiffness matrix). Three critical load combinations with the leading variable load component given in bold are presented: COMB GQS corresponding to the maximal gravity deflection of floor beams, COMB GS corresponding to the combination giving the minimal load factor $\alpha_{\mathrm{ult}}$ and the maximal gravity deflection of roof beams, and finally COMB GWQS corresponding to the maximal frame sway displacement.

Table 2. Load multipliers and verification criteria for original frame - Frame A-CS1

\begin{tabular}{|c|c|c|c|c|c|c|}
\hline \multirow{2}{*}{$\begin{array}{l}\text { Load } \\
\text { combination }\end{array}$} & \multicolumn{2}{|c|}{ Fundamental combination } & \multicolumn{2}{|c|}{ Characteristic combination } & \multicolumn{2}{|c|}{ Frequent combination } \\
\hline & $\begin{array}{l}\text { Name of } \\
\text { combination }\end{array}$ & $\alpha_{\text {ult }, \mathrm{i}}$ & $\begin{array}{l}\text { Name of } \\
\text { combination }\end{array}$ & Maximal deflection & $\begin{array}{l}\text { Name of } \\
\text { combination }\end{array}$ & Maximal deflection \\
\hline COMB GQS & ULS06 & $\begin{array}{l}\alpha_{\text {ult }, 6}=1.29 \\
\text { Strength limit reached } \\
(\operatorname{det} \mathbf{K}=0)\end{array}$ & SLS2k & $\begin{array}{l}\text { Serviceability Limit State: } \\
\boldsymbol{\delta}_{\text {floor }, \mathbf{k}, \mathbf{6} / \boldsymbol{\delta}_{\text {floor,lim }}=\mathbf{1 , 0 0}} \\
\text { Serviceability limit for the } \\
\text { floor beam. }\end{array}$ & SLS1f & $\begin{array}{l}\text { Floor beam } \\
\delta_{\text {floor, }, 6 / 6} / \delta_{\text {floor,lim }}=0,74 \\
\text { Serviceability limit not } \\
\text { exceeded. }\end{array}$ \\
\hline COMB GS & ULS11 & $\begin{array}{l}\text { Ultimate Limit State: } \\
\boldsymbol{\alpha}_{\text {ult }=\boldsymbol{\alpha}_{\text {ult } \mathbf{1 1}=\mathbf{1 . 2 6}}} \\
\text { Strength limit reached } \\
\text { (excessive stiffness } \\
\text { reduction). }\end{array}$ & SLS7k & $\begin{array}{l}\text { Roof beam } \\
\delta_{\text {roof, },, 11} / \delta_{\text {roof,lim }}=0,90 \\
\text { Serviceability limit not } \\
\text { exceeded. }\end{array}$ & SLS3f & $\begin{array}{l}\text { Roof beam } \\
\delta_{\text {roof,f, }, 11} / \delta_{\text {roof,lim }}=0,53 \\
\text { Serviceability limit not } \\
\text { exceeded. }\end{array}$ \\
\hline COMB GWQS & ULS12 & $\begin{array}{l}\alpha_{\mathrm{ult}, 12}=1.33 \\
\text { Strength limit reached } \\
(\operatorname{det} \mathbf{K}=0)\end{array}$ & SLS8k & $\begin{array}{l}\text { Sway upper storey } \\
\delta_{\text {hor, }, 12} / \delta_{\text {hor, lim }}=0,97 \\
\text { Serviceability limit not } \\
\text { exceeded. }\end{array}$ & SLS4f & $\begin{array}{l}\text { Sway upper storey } \\
\delta_{\text {hor.f. } 12} / \delta_{\text {hor,lim }}=0,30 \\
\text { Serviceability limit not } \\
\text { exceeded. }\end{array}$ \\
\hline
\end{tabular}

Fig. 11 shows the degree of stiffness degradation of frame line elements at the strength limit state for each of three considered design load combinations (ULS). The colors gray, from dark to light, indicates the situations from small stiffness reduction till the great stiffness reduction. The following observations can be made:

1. Frame beam elements pinned to columns are more sensitive to stiffness reduction in the middle length where the moments are of the greatest value, frame column elements are less sensitive to stiffness reduction, except the ground floor columns, especially the external one of greatest compression in the combination including live loads and wind loads. This is an effect of the secondary frame, attached to the main frame at the top of the external ground floor column, transferring vertical and horizontal actions onto the main frame.

2. The greatest number of beam and column elements with the smallest stiffness at the ultimate strength state is for the load combination COMB GQS and COMB GWQS. In the combination COMB $\mathbf{S}$ the greatest stiffness reduction is restricted only to roof beams. 
3. The truss bracing elements being in compression are of low stiffness at the strength limit load in all the load combinations. In the COMB GWQS combination not only the truss members being under compression have a very low stiffness at the strength limit load, but also those being under tension. The stiffness of tension truss members is almost unreduced for upper storey while the reduction is greater and greater, considering braces down the successive stories from the top to the bottom of the building.

a)

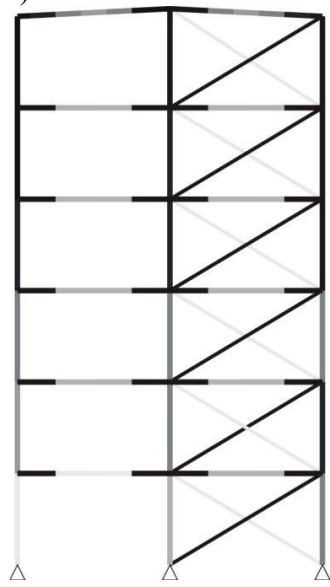

b)

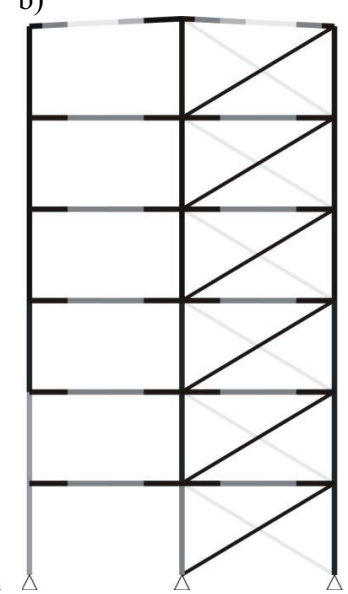

c)

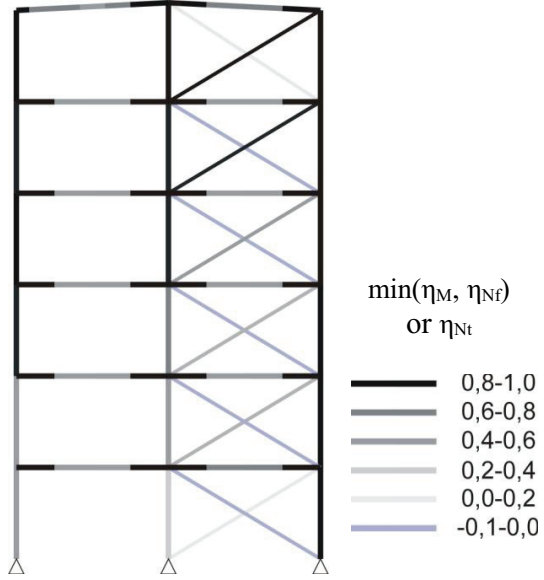

Fig. 11. Graphical illustration of the degree of stiffness reduction of frame elements; a) load combination COMB GQS, b) load combination COMB GS , c) load combination COMB GWQS

In order to compare the robustness of the original frame system (Frame A-CS 1) with regard to the response to different load combinations, the Euclidean norm of loads on the considered structure is evaluated:

$$
F_{d}=\sqrt{\left(\sum_{j} F_{d, v e r, j}\right)^{2}+\left(\sum_{j} F_{d, h o r, j}\right)^{2}}
$$

where:

the summation is done over the degrees of freedom, $F_{d, v e r, j}$ - the vertical load component at the $j$-th degree of freedom, $F_{d, h o r, j}-$ the horizontal component at the $\mathrm{j}$-th degree of freedom. 
The frame stiffness reduction factor $\eta_{\mathrm{M}, \text { tot }}$ is obtained by averaging the sum of stiffness reduction factors $\eta_{M}$ of frame elements for their beginning $\eta_{M, a}$ and end $\eta_{M, b}$ :

$$
\eta_{\mathrm{M}, \mathrm{tot}}=\frac{\sum_{\mathrm{m}=1}^{\mathrm{n}_{\mathrm{f}}}\left(\eta_{\mathrm{M}, \mathrm{a}, \mathrm{m}}+\eta_{\mathrm{M}, \mathrm{b}, \mathrm{m}}\right)}{2 \mathrm{n}_{\mathrm{f}}}
$$

where:

$\eta_{M, a, m}, \eta_{M, b, m}$ - flexural stiffness degradation functions at the beginning " $a$ " and the end " $b$ " of the frame element (in case of semi-continuous frames, the stiffness degradation function is integrated at each member element end with the semi-rigid joint stiffness reduction function in respect to the joint initial stiffness), $\mathrm{m}$ number of frame substructure element, $\mathrm{n}_{\mathrm{f}}-$ total number of frame substructure elements (excluding the brace substructure members).

The frame stiffness reduction factor $\eta_{\mathrm{Nf} \text {,tot }}$ is obtained in a similar way by averaging the sum of stiffness reduction factors $\eta_{\mathrm{Nf}}$ of frame elements:

$$
\eta_{\mathrm{Nf}, \mathrm{tot}}=\frac{\sum_{\mathrm{m}=1}^{\mathrm{n}_{\mathrm{f}}}\left(\eta_{\mathrm{Nf}, \mathrm{m}}\right)}{\mathrm{n}_{\mathrm{f}}}
$$

where:

$\eta_{\mathrm{Nf}, \mathrm{m}}$ - axial stiffness degradation function of the frame element $\mathrm{m}$.

The brace stiffness reduction factor $\eta_{\mathrm{N} t \text { tot }}$ is obtained also in a similar way by averaging the sum of stiffness reduction factors $\eta_{\mathrm{Nt}}$ of brace elements:

$$
\eta_{\mathrm{Nt}, \mathrm{tot}}=\frac{\sum_{\mathrm{k}=1}^{\mathrm{n}_{\mathrm{t}}}\left(\eta_{\mathrm{Nt}, \mathrm{k}}\right)}{\mathrm{n}_{\mathrm{t}}}
$$

where:

$\eta_{\mathrm{Nt}, \mathrm{k}}$ - axial stiffness degradation function of the brace element $\mathrm{k}, \mathrm{n}_{\mathrm{t}}-$ total number of elements within the brace substructure (excluding the frame substructure members).

In the presentation of results illustrating the behaviour of modified structure - Frame A-CS1, the effects of stiffness reduction of the frame and truss bracing on the frame response are also considered with regard to $\eta_{\mathrm{M}, \text { tot }}$ and the range of $\eta_{\mathrm{Nt}}$.

Figs. 12 and 13 present the exemplary results of the structure response $\alpha_{\mathrm{Fd}}$ vs. the dimensionless displacement (actual value referred to the limiting value at SLS) for two load combinations, namely in Fig. 12 for COMB GQS and in Fig. 13 for COMB GWQS. In Fig. 12 the displacement $\delta_{\text {ver, } 19}$ is the 
gravity mid-length deflection of the beam numbered 19, while $\delta_{\text {hor }}$ in Fig. 13 is the horizontal sway deflection of the upper storey, at its top. In Figs. 12 and 13 there are the curves representing the frame stiffness reduction factor $\eta_{\mathrm{M}, \text { tot }}$ while additionally:

1. In Fig. 13 there is the function of $\eta_{M}$ for the most strained frame substructure element (no. 19).

2. In Fig. 14 there is the darkened area bounded by the upper and lower curves $\eta_{\mathrm{N}, \mathrm{t}}$, representing the range of stiffness reduction of truss bracing members being under tension and compression.
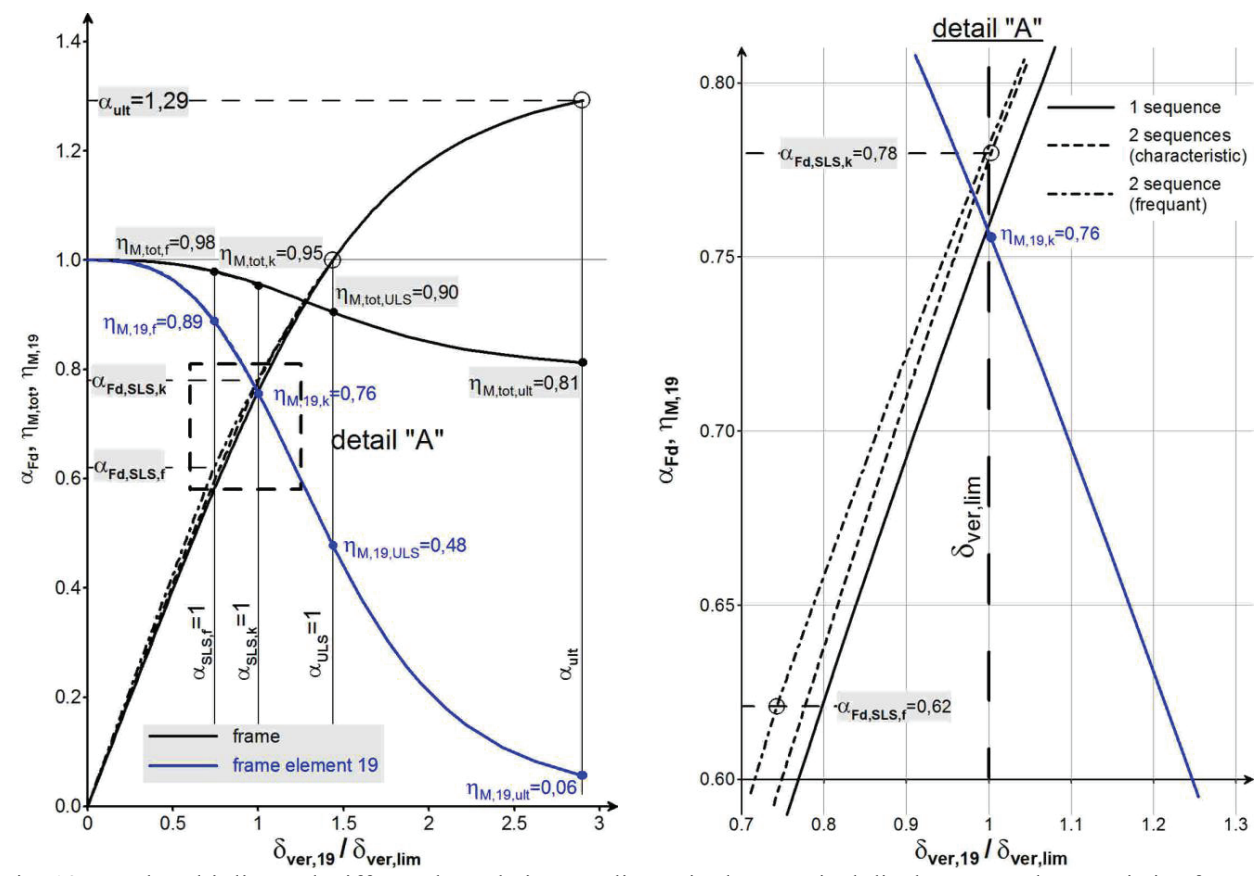

Fig. 12. Load multiplier and stiffness degradation vs. dimensionless vertical displacement characteristics for

\section{COMB GQS}

The following conclusions can be drawn:

1. ULS verification: for the partial resistance factor $\gamma_{\mathrm{M} 1}=1$, the minimal value of design load multipliers $\alpha_{\text {ult,i, }}$ evaluated from all possible fundamental load combinations, passes the level $\alpha_{\text {ult }}=1$ (where $\alpha_{\mathrm{ult}}=\mathrm{F}_{\mathrm{ult}} / \mathrm{F}_{\mathrm{d}, \mathrm{ULS}}=1$ corresponds to the unfavorable fundamental load combination). The load multiplier $\alpha_{\text {ult }} \geq 1$ evaluated for the unfavorable fundamental load combination describes the safety margin of the designed structure (where $\alpha_{\mathrm{ult}}=\mathrm{F}_{\mathrm{ult}} / \mathrm{F}_{\mathrm{d}, \mathrm{ULS}} \geq 1$ corresponds to the limit point on the structure equilibrium path). 
2. SLS verification: for all the design characteristic or frequent load combinations $\alpha_{S L S, i}=1$, the maximal serviceability utilization ratio for vertical gravity and horizontal sway displacements $\delta_{\text {ser }} / \delta_{\text {lim }}$ is less or at the most equal to unity (where $\alpha_{\mathrm{SLS}}=\mathrm{F}_{\mathrm{d}} / \mathrm{F}_{\mathrm{d}, \mathrm{SLS}}=1$ corresponds to the characteristic or frequent combination load level).

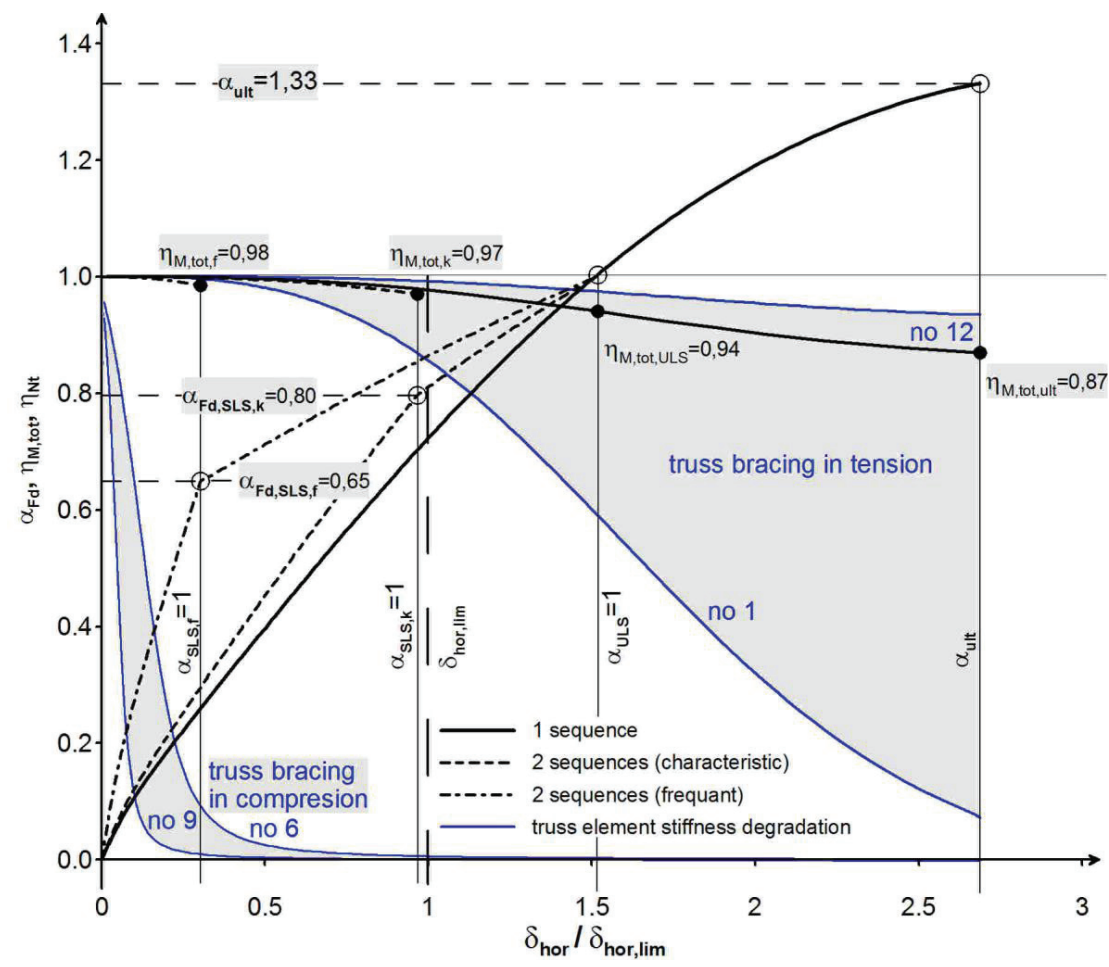

Fig. 13. Load multiplier and stiffness degradation vs. dimensionless horizontal displacement characteristics for COMB GWQS

3. The example of braced frame addresses the real expertise in which the assessment of ULS and SLS criteria were involved using the direct design method. Advanced analysis shows that both the SLS and ULS criteria of the original frame (Frame A-CS1) are not violated. The structure has an adequate margin of safety of around $25 \%$ but at the same time it reaches SLS. An additional resistance demand associated with the increased loads as a result of change of the building function would result in the violation of SLS requirements but not necessary the violation of ULS requirements. 
4. Although the ultimate limit state is associated with the singular stiffness matrix (excluding $\alpha_{\text {ult }}$ for COMB GS where the local failure mechanism of the roof beam governs), it has to be emphasized that the column no. 1 of the lowest storey has at the top the minimal axial stiffness ( $\eta_{\mathrm{Nf}}=0,11$ while $\left.\eta_{\mathrm{M}}=1\right)$. For the most strained and most deflected beam no. 19 of the lowest storey, the stiffness reduction factors are just of opposite values $\left(\eta_{\mathrm{Nf}}=0,99\right.$ while $\left.\eta_{\mathrm{M}}=0,23\right)$.

\subsection{NUMERICAL RESULTS OF FRAME A-CS2}

The frame considered in subsection 4.4 was reinforced after some years of its service life and the modified frame (Frame A-CS2) is modelled hereafter. In Frame A-CS2, the sectional area of selected members were increased. The modified elements are: roof beams (being the weakest elements with regard to their resistance requirements) and floor beams (since they are the weakest elements with regard to their serviceability requirements). The reinforcement was done by welding the steel cover plates to flanges of original beam sections. Since under some load combinations the resistance margin of some columns and brace members was too low, their cross sectional area were also increased. In Fig. 14 the reinforced structural elements were marked by blue color.
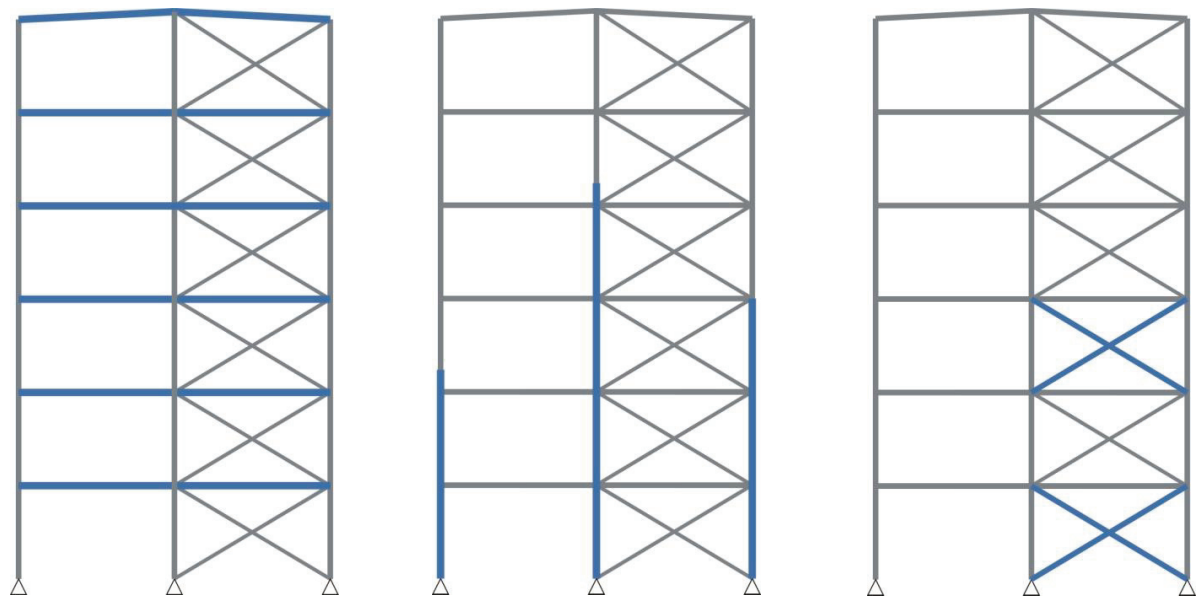

Fig. 14 Reinforced frame elements: a) beams, b) columns, c) bracing bars

The advanced CSD analysis was carried out for all the load combinations given in Table 1, as it was done for the original frame, Frame A-CS 1 (the results of Frame A-CS 1 simulations are listed Table 2). The most representative results of Frame A-CS 2 simulations are presented in Table 3 for 
the purpose of their direct comparison with those obtained for Frame A-CS 1. Since for Frame A-CS 1, with members of lesser cross sectional areas, the serviceability utilization ratios were below unity even for the design characteristic load combinations, in the SLS verification of Frame A-CS 2 the design frequent load combinations were neglected.

Table 3. Load multipliers and verification criteria for modified frame - Frame A-CS 2

\begin{tabular}{|c|c|c|c|c|}
\hline \multirow{2}{*}{$\begin{array}{l}\text { Load } \\
\text { combination }\end{array}$} & \multicolumn{2}{|c|}{ Fundamental combination } & \multicolumn{2}{|c|}{ Characteristic combination } \\
\hline & Name of combination & $\alpha_{\mathrm{ult}, \mathrm{i}}$ & Name of combination & Maximal deflection \\
\hline COMB GQS & ULS06 & $\begin{array}{l}\alpha_{\text {ult }, 6}=1.72 \\
\text { Strength limit reached } \\
(\operatorname{det} \mathbf{K}=0)\end{array}$ & SLS2k & $\begin{array}{l}\text { Floor beam } \\
\delta_{\text {floor, }, 6} / \delta_{\text {floor,lim }}=0,66 \\
\text { Serviceability limit not exceeded. }\end{array}$ \\
\hline COMB GS & ULS11 & $\begin{array}{l}\alpha_{\mathrm{ult}=} \alpha_{\mathrm{ult}, 11}=1.88 \\
\text { Strength limit reached (excessive } \\
\text { stiffness reduction). }\end{array}$ & SLS7k & $\begin{array}{l}\text { Roof beam } \\
\delta_{\text {roof,k,11 }} / \delta_{\text {roof,lim }}=0,47 \\
\text { Serviceability limit not exceeded. }\end{array}$ \\
\hline COMB GWQS & ULS12 & $\begin{array}{l}\text { Ultimate Limit State: } \\
\boldsymbol{\alpha}_{\text {ult,12 }}=\mathbf{1 . 5 7} \\
\text { Strength limit reached (excessive } \\
\text { stiffness reduction). }\end{array}$ & SLS8k & $\begin{array}{l}\text { Sway upper storey } \\
\delta_{\text {hor, }, 12} / \delta_{\text {hor,lim }}=0,81 \\
\text { Serviceability limit not exceeded. }\end{array}$ \\
\hline
\end{tabular}

Reinforcement of the roof beams resulted in an import increase of $\alpha_{\mathrm{ult}}$ and the change in failure modes of the modified structural system (minimal value of $\alpha_{u l t, i}$ is associated with the load combination COMB GQS instead of COMB GS, i.e. $\alpha_{\text {ult }}=\alpha_{\text {ult }, 11}$ instead of $\left.\alpha_{u l t}=\alpha_{u l t, 6}\right)$. After the reinforcement of the floor beams, their gravity displacements decreased of almost $15 \%$. Maximal value of beam gravity displacements became therefore well below the serviceability limit. Considering the multistage way of the frame members reinforcement introduction, it may be concluded that reinforcing the beam sections alone did not affect the global frame resistance. Multipliers $\alpha_{\mathrm{ult}, 6}$ and $\alpha_{\mathrm{ult}, 11}$ for Frame A-CS1 and Frame A-CS2 remain at the similar level. The situation radically improves when additional reinforcement is made for columns. It was shown however that the columns reinforcement could not have been fully utilized since bracing members are too weak, even after their reinforcement. The truss members stiffness degradation was a decisive factor for the frame collapse load multiplier $\alpha_{\mathrm{ult}}=\alpha_{\mathrm{ult}, 12}$ attainment, corresponding to COMB GWQS, the combination with the live and wind load variable components. In case of the greater reinforcement of bracing substructure members of two lowest storeys, the ULS11 load multiplier would be of a greater value than that for the combination ULS06 of the modified frame studied in this subchapter (i.e. $\alpha_{\text {ult }}$ for Frame A-CS 2 would be referred back to $\alpha_{\text {ult,6 }}$, analogically like for Frame A-CS 1). 
In Figs. 15 and 16 there are compared the load-displacement curves and the stiffness degradation functions for Frame A-CS1 and Frame A-CS2. The dimensionless coordinates are used in which the ordinate represents the load multiplier while the abscissa represents the selected deformation load effect divided by the serviceability deformation limit. The results for Frame A-CS1 are in grey colour.

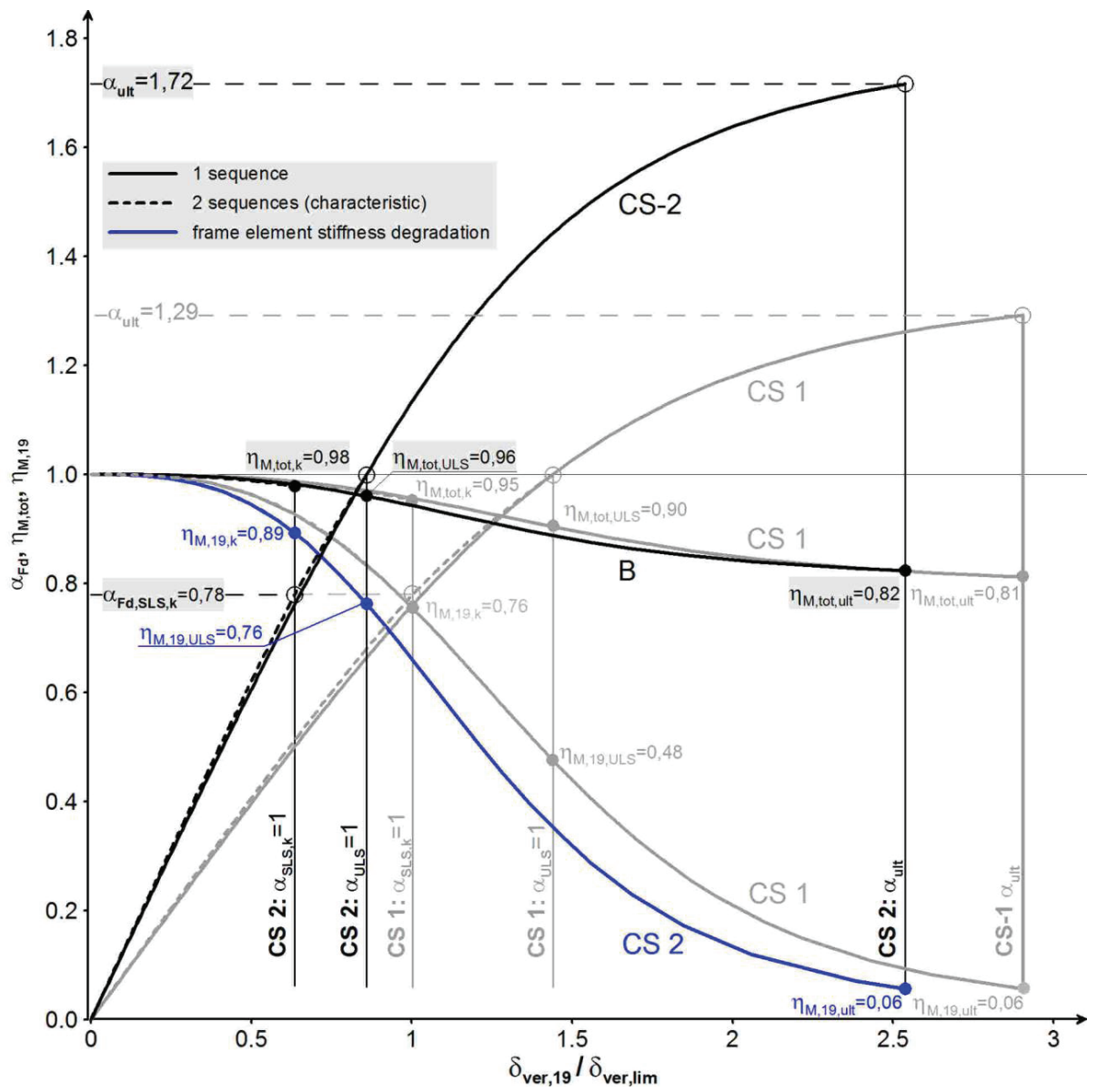

Fig. 15 Frame A load multiplier and stiffness degradation vs. vertical displacement relationships for COMB GQS

The comparison of static equilibrium paths $\alpha_{\mathrm{Fd}}-\delta_{\mathrm{ver}, 19} / \delta_{\mathrm{ver}, \mathrm{lim}}$ of Frame A-CS1 and Frame A-CS2 shows the increase of the global Frame A-CS 2 stiffness in reference to Frame A-CS1. Similarly, the stiffness degradation curves $\eta_{\mathrm{M}}-\delta_{\mathrm{ver}, 19} / \delta_{\mathrm{ver}, \text { lim }}$ of Frame A-CS1 are placed above those corresponding to Frame A-CS2. For the load level $\mathrm{F}_{\mathrm{d}, \mathrm{ULS}}$, the stiffness of beam 19 of Frame A-CS2 is placed well 
above that for Frame A-CS1. The stiffness degradation curves corresponding to the entire structure, and the values corresponding to the load level $\mathrm{F}_{\mathrm{d}, \mathrm{SLS}}$ are however closer to each other than those for the beam 19 .

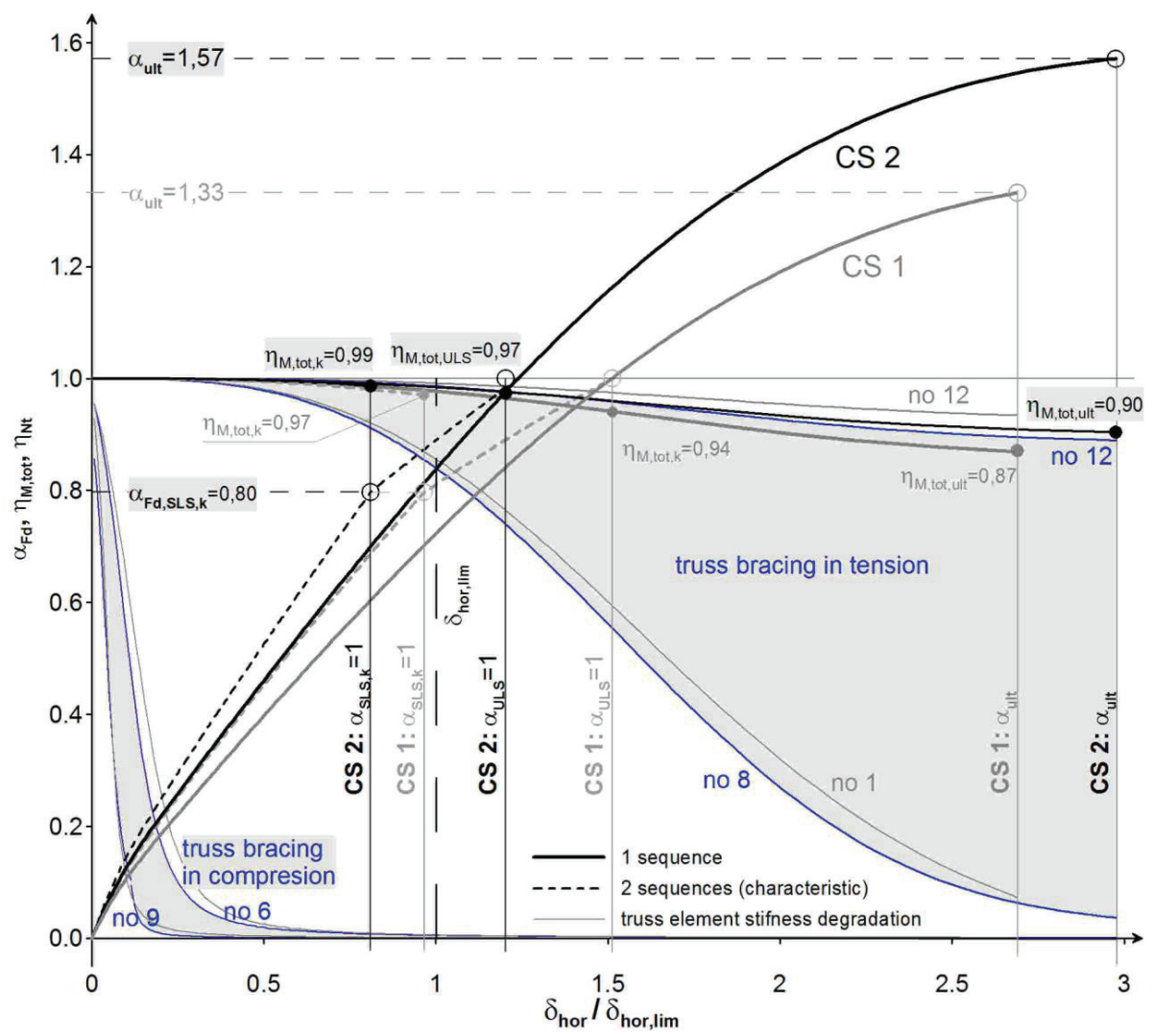

Fig. 16 Load multiplier and stiffness degradation vs. horizontal displacement relationships for COMB GWQS

For the load combination COMB GWQS, in line with the combination COMB GQS, the load multiplier $\alpha_{\text {ult,i is }}$ greater for Frame A-CS2 as a result of the columns reinforcement.

Comparing the response of the truss bracing members of Frame A-CS1 and Frame A-CS2 one can conclude that the picture is more complex than that for the frame substructure members. The darkened region, identified by the upper and lower bounding curves of the brace stiffness degradation curves. Despite of the effect associated with lowering of the Frame A-CS2 stiffness degradation curves 
envelope, the stiffness degradation factors $\eta_{\mathrm{Nt}}$ for different braces in Frame A-CS1 and Frame A-CS2 are of different values at the same load level. The picture is however disrupted by the fact that some braces were reinforced, e.g. by reinforcing brace no. 1 of Frame A-CS1, in Frame A-CS2 this brace is no longer the weakest truss element in tension. Its role as the weakest element is taken over by the brace no. 8 .

\section{ASSESSMENT OF LIMIT STATES FOR DIFFERENT JOINT DETAILING}

The same framework geometry is considered as for the simple construction in the previous section. Member properties are kept the same as in Frame A-CS1, called hereafter Frame A. The only difference is that the present chapter is concerned with the braced frame system in which the joints with nonzero stiffness characteristic are dealt with, instead of beam-to-column nominally pinned joints.

\subsection{FLEXIBLE BEAM-TO-COLUMN JOINTS AND MODELLING OF SEMI-CONTINUOUS BRACED FRAME}

The structural arrangement with semi-rigid joints is referred to Frame B. The beam-to-column joints of Frame B are presented in Fig. 17. They are arranged with bolted flush end-plates the thickness of which is the same as for Frame A. The bolt diameter is also the same but of a higher grade in order to avoid the situation that tension bolts constitute the weakest link of the joint components.

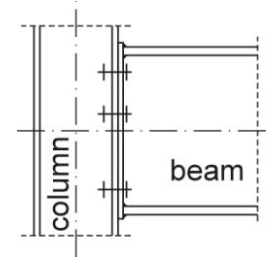

Fig. 17 The modified beam-to-column joint detail of Frame B

The joint properties, initial stiffness $S_{j, \text { ini }}$ and the moment resistance $M_{j, R}$ given in Table 4 were calculated by the component method of Eurocode 3, Part 1.8 [23], as well as classified as semi-rigid and partial-strength joints. The joint CSD moment-rotation characteristic is modeled in the way explained in [15] that has been adopted in the computer software. This nonlinear characteristics gives 
the simulation results practically the same as those obtained with use of the Eurocode 3 characteristic being elastic up to the level of two-third of $\mathrm{M}_{\mathrm{j}, \mathrm{R}}$ and nonlinear elastic-plastic, between the level of $2 \mathrm{M}_{\mathrm{j}, \mathrm{R}} / 3$ and that of the joint resistance $\mathrm{M}_{\mathrm{j}, \mathrm{R}}$.

Table 4. Stiffness and strengths of semi-continuous joints

\begin{tabular}{|c|c|c|c|c|c|}
\hline \multirow{3}{*}{ Column sections } & \multirow{3}{*}{ Beam sections } & \multicolumn{2}{|c|}{ External joints } & \multicolumn{2}{|c|}{ Internal joints } \\
\hline & & Stiffness $S_{j, \text { ini }}$ & Resistance $M_{j, R}$ & Stiffness $S_{j, i n i}$ & Resistance $M_{j, R}$ \\
\hline & & $\mathrm{kNm} / \mathrm{rad}$ & $\mathrm{kNm}$ & $\mathrm{kNm} / \mathrm{rad}$ & $\mathrm{kNm}$ \\
\hline H 200x18x200x34 & \multirow{4}{*}{ I 400x6x180x16 } & & & 67090 & \multirow{2}{*}{79,4} \\
\hline $\mathrm{H} 200 \times 18 \times 200 \times 26$ & & 35600 & 79,4 & 66145 & \\
\hline H 200x12x200x18 & & 26500 & 69,9 & & \\
\hline $\mathrm{H} 200 \times 12 \times 200 \times 14$ & & 26050 & 73,3 & 46100 & 82,9 \\
\hline H 200x12×200x14 & IPE 270 & 11240 & 42,1 & 16500 & 46,1 \\
\hline
\end{tabular}

As in the CSD advanced analyses carried out for Frame A, all the load combinations listed in Table 1 were considered. The results presented hereafter are concerned with the load combinations governing the failure criterion of Frame A (see Table 5).

Table 5. Load multipliers and verification criteria for semi-continuous frame

\begin{tabular}{|c|c|c|c|c|}
\hline \multirow{2}{*}{$\begin{array}{l}\text { Load } \\
\text { combination }\end{array}$} & \multicolumn{2}{|c|}{ Fundamental combination } & \multicolumn{2}{|c|}{ Characteristic combination } \\
\hline & Name of combination & $\alpha_{\text {ult }, \mathrm{i}}$ & Name of combination & Maximal deflection \\
\hline COMB GQS & ULS06 & $\begin{array}{l}\text { Ultimate Limit State: } \\
\boldsymbol{\alpha}_{\text {ult }=} \boldsymbol{\alpha}_{\text {ult }, \mathbf{6}}=\mathbf{1 . 2 2} \\
\text { Strength limit reached } \\
\text { (excessive stiffness reduction). }\end{array}$ & SLS2k & $\begin{array}{l}\text { Floor beam } \\
\delta_{\text {floor, }, 6} / \delta_{\text {floor,lim }}=0,63 \\
\text { Serviceability limit not exceeded. }\end{array}$ \\
\hline COMB GS & ULS11 & $\begin{array}{l}\alpha_{\mathrm{ult}, 11}=1.73 \\
\text { Strength limit reached (excessive } \\
\text { stiffness reduction). }\end{array}$ & SLS7k & $\begin{array}{l}\text { Roof beam } \\
\delta_{\text {roof,k,11 }} / \delta_{\text {roof,lim }}=0,40 \\
\text { Serviceability limit not exceeded. }\end{array}$ \\
\hline COMB GWQS & ULS12 & $\begin{array}{l}\alpha_{\mathrm{ult}, 12}=1.33 \\
\text { Strength limit reached }(\operatorname{det} \mathbf{K}=0) \text {. }\end{array}$ & SLS8k & $\begin{array}{l}\text { Sway upper storey } \\
\delta_{\text {hor,k,12}} / \delta_{\text {hor,lim }}=0,92 \\
\text { Serviceability limit not exceeded. }\end{array}$ \\
\hline
\end{tabular}

As one would have been expected, the joint reinforcement resulted in the visible decrease of the beam displacements as a result of the moment transfer from the beams onto the columns, enabled by semirigid joints. The beneficial effect of joint modification resulted in a lesser safety margin of the semicontinuous braced system of Frame B. The moment transfer possible for Frame B from the beams onto the columns, resulted in columns being weaker than in case of Frame A. The columns of Frame B were subjected to a greater stiffness reduction $\eta_{M}$ than in Frame A. The flexural stiffness reduction, represented by the degradation functions $\eta_{M}$ is greater for Frame B because greater values of moments 
in columns are associated with practically the same level of the axial stiffness reduction as observed for Frame A (represented by the degradation function $\eta_{\mathrm{Nf}}$ ). The same load multiplier is observed for the load combination COMB GWQS (with wind being the leading variable load component) for which $\alpha_{\text {ult, } 12}=1,33$. The noticeable increase of $\alpha_{\text {ult }}$ is observed for the combination COMB GS (with snow) for which $\alpha_{\text {ult,11 }}=1,73$ as a differential increase of the section moment resistance in the middle length of the roof beams. For Frame A, the collapse load multiplier was associated with the formation of plastic hinge in the mid-length of roof beams.

\subsection{RIGID BEAM-TO-COLUMN JOINTS AND MODELLING OF CONTINUOUS BRACED FRAME}

The last example is concerned with the modification of Frame A beam-to-column joints in such a way that extended end-plate of bolted joints fulfill the requirements of Eurocode 3, Part 1-8 [23] for nominally rigid joints. The rigid joint frame is marked as Frame $\mathrm{C}$.

The results of CSD advanced analysis are presented in Table 6. It may be concluded that the SLS criteria are fulfilled with a greater margin than in cases of Frame A and B. Because the moment transfer from the beams onto the columns is greater than in case of Frame B, the stiffness reduction is progressing faster under the load incrementation, resulting in a further decrease of the safety margin if compared with results for Frame B.

Table 6. Load multipliers and verification criteria for rigid frame

\begin{tabular}{|c|c|c|c|c|}
\hline \multirow{2}{*}{$\begin{array}{l}\text { Load } \\
\text { combination }\end{array}$} & \multicolumn{2}{|c|}{ Fundamental combination } & \multicolumn{2}{|c|}{ Characteristic combination } \\
\hline & Name of combination & $\alpha_{\text {ult }, \mathrm{i}}$ & Name of combination & Maximal deflection \\
\hline COMB GQS & ULS06 & $\begin{array}{l}\text { Ultimate Limit State: } \\
\boldsymbol{\alpha}_{\text {ult }=} \boldsymbol{\alpha}_{\text {ult }, \mathbf{6}}=\mathbf{1 . 1 8} \\
\text { Strength limit reached } \\
\text { (excessive stiffness reduction). }\end{array}$ & SLS2k & $\begin{array}{l}\text { Floor beam } \\
\delta_{\text {floor, }, 6} / \delta_{\text {floor,lim }}=0,35 \\
\text { Serviceability limit not exceeded. }\end{array}$ \\
\hline COMB GS & ULS11 & $\begin{array}{l}\alpha_{\text {ult }, 11}=1.81 \\
\text { Strength limit reached (excessive } \\
\text { stiffness reduction). }\end{array}$ & SLS7k & $\begin{array}{l}\text { Roof beam } \\
\delta_{\text {roof, }, 11} / \delta_{\text {roof,lim }}=0,23 \\
\text { Serviceability limit not exceeded. }\end{array}$ \\
\hline COMB GWQS & ULS12 & $\begin{array}{l}\alpha_{\mathrm{ult}, 12}=1.22 \\
\text { Strength limit reached }(\operatorname{det} \mathbf{K}=0)\end{array}$ & SLS8k & $\begin{array}{l}\text { Sway upper storey } \\
\delta_{\text {hor,k,12 }} / \delta_{\text {hor,lim }}=0,84 \\
\text { Serviceability limit not exceeded. }\end{array}$ \\
\hline
\end{tabular}




\subsection{COMPARISON OF RESULTS}

Frame load-displacement characteristics obtained for frames with different joint properties, namely Frame A-CS1 with nominally pinned beam-to-column joints, Frame B with semi-rigid joints and Frame $\mathrm{C}$ with nominally rigid joints, are shown in Figs. 18 and 19. The results for above mentioned three frames are represented by three shades of grey colour.

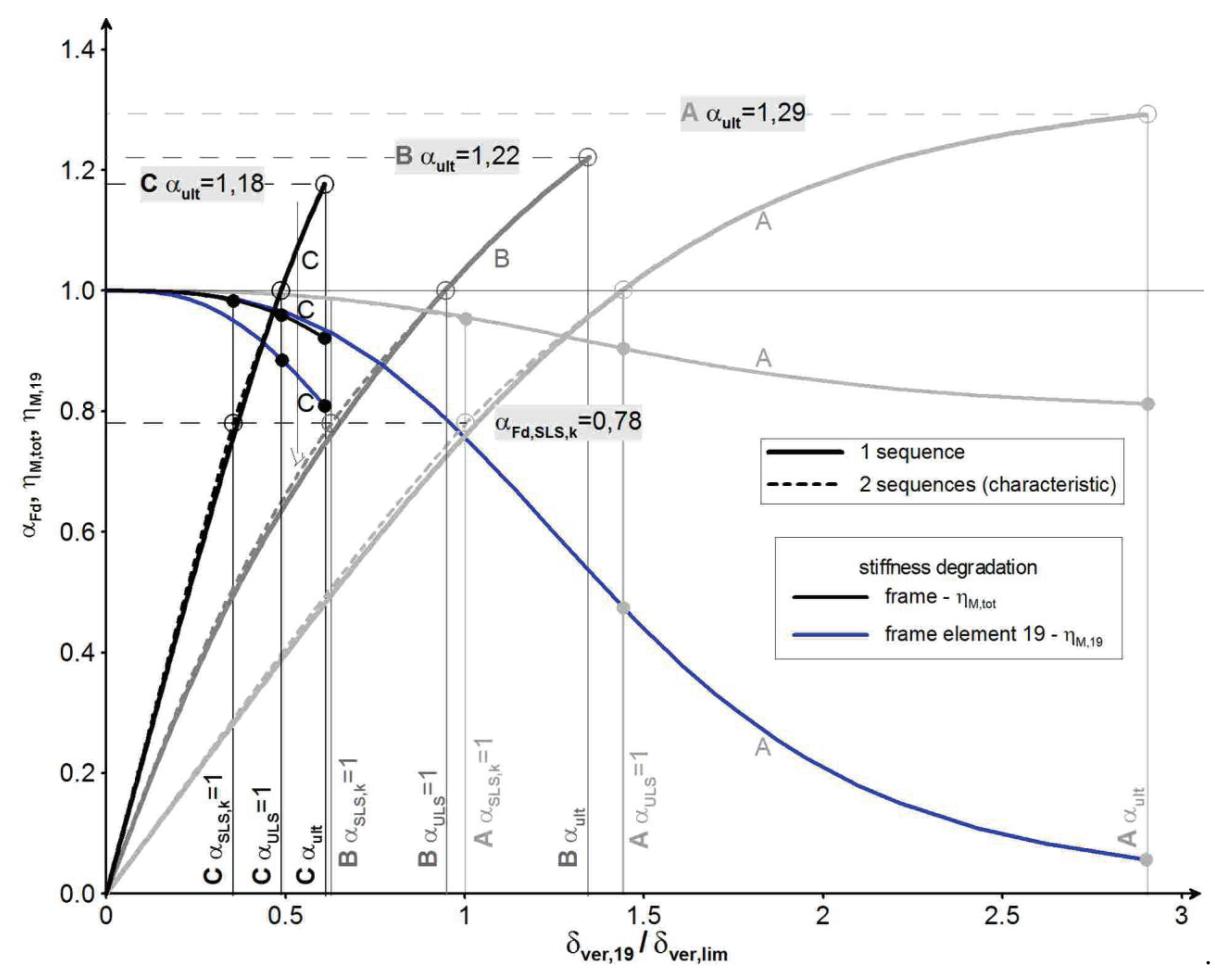

Fig. 18 Load multiplier and stiffness degradation vs. vertical displacement relationships

Fig. 18 presents the results with reference to the displacement state of the beam no. 19. When the joint stiffness is being increased, the limit point on the equilibrium path is characterized by the lower value of the load multiplier $\alpha_{\text {ult. }}$ Load deformation effects (gravity and sway displacements) and the frame ductility are continuously being decreased. The well known effect is confirmed that in braced frames with the same geometry and member properties but with more stiff joints, the safety margin is subjected to decrease. The greater moments transferred onto the columns results in a faster 
degradation of the column stiffness, especially for the outer columns, reaching the negative trace of the stiffness matrix at the ultimate limit state. The collapse load is dominated by small values of the column stiffness of frame lower storeys that may be represented by the product of multiplication of stiffness degradation factors $\eta_{M}$ and $\eta_{N f}$. The total stiffness reduction curve $\eta_{M}$,tot of Frame $C$ (rigid frame) is placed lower than that of Frame A (simple construction). The conclusion is that $\eta_{\mathrm{M}, \text { tot }}$ curves for any other joint stiffness between nominally pinned and nominally rigid would be placed between two above mentioned.

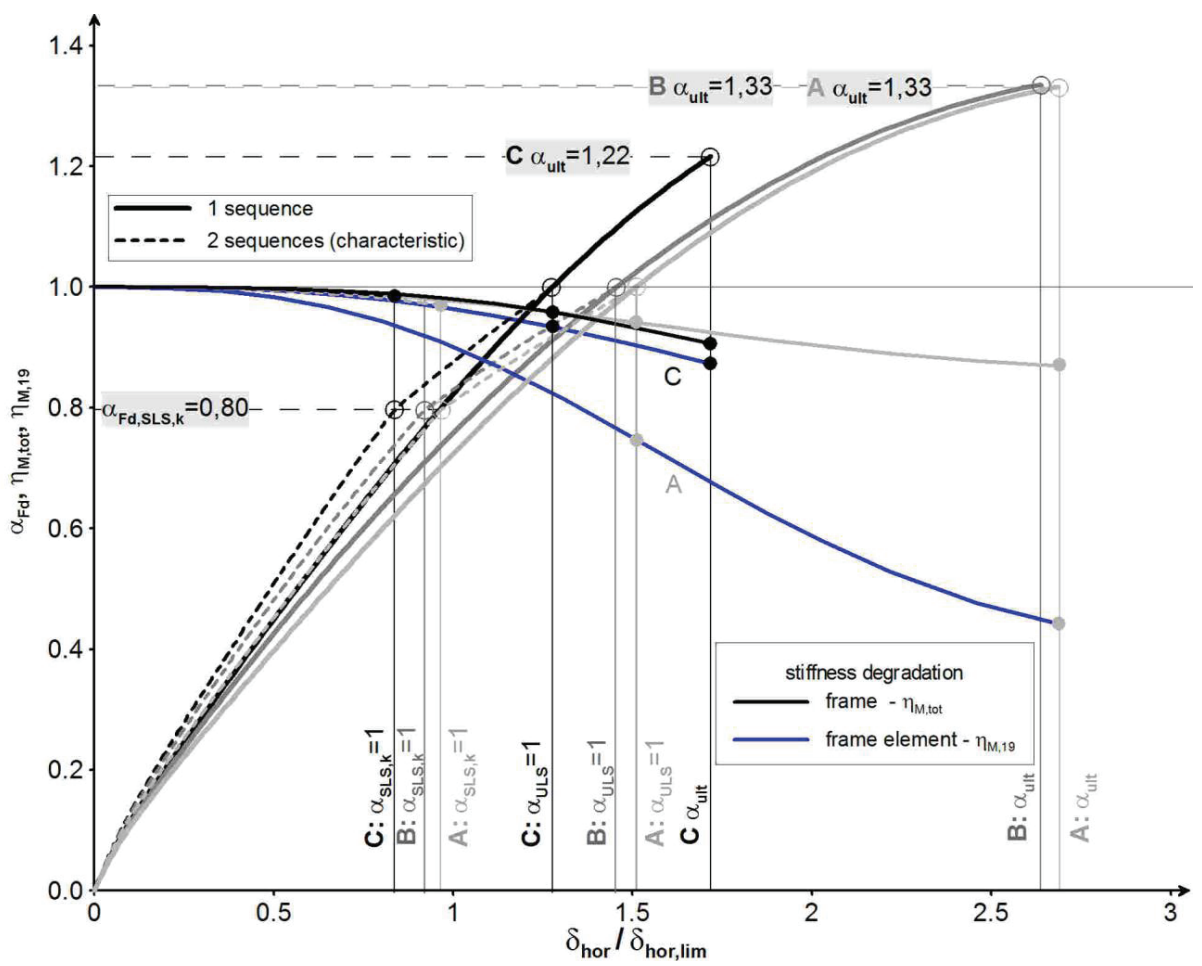

Fig. 19 Load multiplier and stiffness degradation vs. horizontal displacement relationships

Fig. 19 presents the results referred to the sway displacement at the top of the frame. Comparing the results in Fig. 18 and Fig. 19, one can observe that the load-displacements curves in Fig. 19 are much closer to each other than those in Fig. 18 but the tendency in the frame behavior remains the same. For frames with joints of a stronger stiffness, the stiffness reduction decreasing in beams is not balanced by the increase of the stiffness reduction in columns. Since the columns are under combined 
load effects (moments transferred by flexible joints and axial forces from gravity loads), the reduction of their stiffness is faster than the slower reduction of the beams stiffness. The degradation function $\eta_{M}$ is decreasing fast while $\eta_{\mathrm{Nf}}$ is practically not dependent upon the joint arrangement and governed by the almost the same axial loads in columns the values of which are those of gravity loads summed up from the top storey down to the ground level.

\section{SUMMARY AND CONCLUDING REMARKS}

The implementation of developed CSD advanced analysis in the direct design and the assessment of limit states methodology is presented in this study. The developed flow chart is applicable to design of new structures or redesigning of existing structures in case of a new function designated for the building (double load sequence path) or to the assessment of the resistance of existing structure (single load sequence path).

The implementation of the CSD advanced analysis is illustrated using the real case of the simple construction (braced frame structural system), the expertise of which was carried out at the Warsaw University of Technology. The structure considered was analysed in to variants, Frame A-CS1 - the structure originally erected and Frame A-CS2 - the structure with reinforced members made during service. Next, the three imaginary structures were dealt with for which the geometry and member properties were those of Frame A but with a nonzero beam-to-column joint stiffness, representing the semi-continuous frame (Frame B) and the continuous frame (Frame C). An effort was made to show different opportunities in the assessment of ULS and SLS using the developed strategy in conjunction with the implementation of CSD advanced analysis.

The following attributes hold with regard to the application of the direct method of design:

1. Method of CSD advanced analysis of steel braced frameworks and its implementation into engineering computer software allow for practical application of the direct design method.

2. The adopted brace model accounts for the post-limit behavior and its influence on the inelastic redistribution of forces in the truss bracing substructure.

3. In addition to the margin of safety assessment, there is an opportunity to trace the stiffness reduction of structural elements in intermediate equilibrium states under SLS and ULS load combinations that facilitates the decision making process of structural modification.

4. Presented examples prove that the design-assessment process of braced framework is complex requiring very careful monitoring of the stiffness reduction with the effect of post-limit stiffness softening of truss members taken into account in case of any structural changes for the evaluation of 
overall frame as well as local member and joint responses, and the appearance of structural limit states. The developed CSD advanced analysis software would be of a great help in facilitation of this complex process in a friendly way.

\section{REFERENCES}

1. EN 1993-1-6: Eurocode 3: Design of steel structures - Part 1-7: Strength and stability of planar plated structures subject to out of plane loading, Brussels, CEN, 2007

2. EN 1993-1-1, Eurocode 3: Design of steel structures. Part 1-1: General rules and rules for buildings, Brussels: CEN, 2005.

3. Design of Steel Structures. ECCS Eurocode Design Manuals, 2016

4. N. S. Trahair, M. A. Bradford, D. Nethercot, L. Gardner," The Behaviour and Design of Steel Structures to EC3", Taylor \& Francis, 2008

5. H. Gorgun, "Geometrically nonlinear analysis of plane frames composed of flexibly connected members", Structural Engineering and Mechanics, International Journal, 45 (3), 277-309, 2013.

6. P. H. R. Valipour, M. A. Bradford, "Nonlinear P-D analysis of steel frames with semi-rigid connections", Steel and Composite Structures, 14 (1), 1-20, 2013.

7. C. Nguyen, N. T. N. Doan, C. Ngo-Huu, S. E. Kim, "Nonlinear inelastic response history analysis of steel frame structures using plastic-zone method", Thin-Walled Structures, 85, 220-233, 2014.

8. M. Kucukler, L. Gardner, L. Macorini, "Development and assessment of a practical stiffness reduction method for the in-plane design of steel frames", Journal of Constructional Steel Research, 126, 187-200, 2016.

9. S. L. Chan, Y. P. Liu, S. W. Liu, "A New Codified Design Theory of Second-order Direct Analysis for Steel and Composite Structures - From Research to Practice", Structures, 9, 105-111, 2017.

10. N. S. Trahair, S.-L. Chan, "Out-of-plane advanced analysis of steel structures", Engineering Structures, 255, $1627-1637,2003$

11. C. Ngo-Huu, S. E. Kim, "Practical advanced analysis of space steel frames using fiber hinge method", ThinWalled Structures, 47 (4), 421-430, 2009

12. H. T. Thai, S. E. Kim, "Nonlinear inelastic analysis of space frames", Journal of Constructional Steel Research, 2011

13. S. W. Liu, Y. P. Liu, S. L. Chan, " Direct analysis by an arbitrarily located plastic hinge element. Part 2: Spatial analysis", Journal of Constructional Steel Research, 2014

14. A. Surovek, J. Hajjar, D. Comotim, D. W. White, B. N. Alemdar, R. Ziemian, "Advanced Analysis in Steel Frame Design: Guidelines for Direct Second-Order Inelastic Analysis, ASCE, Ed. A.E. Surovek, 2013

15. A. M. Barszcz, "Validation of CSD adwanced analysis of braced frame responses using subframe experimental investidations", Archives of Civil Engineering [in press]

16. M. Gizejowski, A. M. Barszcz, "Advanced analysis of braced steel frames. Modelling accounting for the postlimit behaviour of compressed angle braces" 8th European Conference on Steel and Composite Structures / Jonsson Jeppe ( red. ), 2017, Ernst \& Sohn Verlag, ss. 1-10

17. AISC. Load and Resistance Factor Design Specifications for structural steel buildings. Chicago: American Institute of Steel Construction; 2005

18. A. M. Barszcz, "Experimentally assisted modelling of the behaviour of steel angle brace", Archives of Civil Engineering, LX (1), pp. 3-39, 2014.

19. EN 1990: Eurocode: Basis of structural design, CEN, 2002

20. EN 1991: Eurocode 1: Actions on structures - Part 1-1: General actions - Densities, self-weight, imposed loads for buildings, CEN, 2008

21. EN 1991-1-3: Eurocode 1: Actions on structures - Part 1-3: General actions - Snow loads, CEN, 2003

22. EN 1991-1-4: Eurocode 1: Actions on structures - Part 1-4: General actions - Wind actions, CEN, 2005

23. EN 1993-1-8: Eurocode 3: Design of steel structures - Part 1-8: Design of joints, CEN, 2005 


\section{LIST OF FIGURES AND TABLES:}

Fig. 1. Flow chart of structural assessment paths for selected load combinations

Rys. 1 Schemat blokowy ścieżek oceny konstrukcji dla wybranych kombinacji obciążeń

Fig. 2. Illustration of stiffness degradation function $\eta_{N \mathrm{~N}}$; a) Hypothetical stress-strain relationship, b) Stiffness degradation function in terms of dimensionless stress

Rys. 2 Ilustracja funkcji degradacji sztywności $\eta_{\mathrm{N} t}$ a) Hipotetyczna zależność naprężenie-odkształcenie,

b) Funkcja degradacji sztywności w odniesieniu do bezwymiarowego naprężenia

Fig. 3. Mises truss considered: a) geometry and loading, b) truss elements and their connection with gusset plates

Rys. 3 Rozważana kratownica Misesa: a) geometria i obciążenie, b) element kratownicy i jego połączenie $\mathrm{z}$ blachami węzłowymi

Fig. .4. Vertical load vs the member rotation curves and axial force vs the stiffness degradation factor curves for the adopted truss member lengths; a) $\mathrm{L}=1000 \mathrm{~mm}, \mathrm{~b}) \mathrm{L}=1500 \mathrm{~mm}$

Rys. 4 Krzywe obciążenie pionowe w funkcji obrotu elementu i siła osiowa w funkcji współczynnika degradacji sztywności dla elementów kratownicy o długości: a) ) L=1000 mm, b) L=1500 mm

Fig. 5. Horizontal load vs the member rotation curves and axial force vs the stiffness degradation factor curves for the adopted truss member lengths; a) $\mathrm{L}=1000 \mathrm{~mm}, \mathrm{~b}$ ) $\mathrm{L}=1500 \mathrm{~mm}$

Rys. 5 Krzywe obciążenie poziome w funkcji obrotu elementu i siła osiowa w funkcji współczynnika degradacji sztywności dla elementów kratownicy o długości: a) L=1000 mm, b) L=1500 mm

Fig. 6. Numerical results in case of the low horizontal force: a) load-member 1-rotation curves, b) stiffness degradation factor $\eta_{\mathrm{Nt}}$

Rys. 6 Wyniki obliczeń numerycznych w przypadku małej siły poziomej: a) krzywe obciążenie - obrót elementu 1, b) współczynnik degradacji sztywności $\eta_{\mathrm{Nt}}$

Fig. 7. Numerical results in case of the high horizontal force: a) load-member-1-rotation curves, b) stiffness degradation factor $\eta_{\mathrm{Nt}}$

Rys. 7 Wyniki obliczeń numerycznych w przypadku dużej siły poziomej: a) krzywe obciążenie - obrót elementu 1, b) współczynnik degradacji sztywności $\eta_{\mathrm{Nt}}$

Fig. 8. Simple construction considered for the limit states calculations

Rys. 8 Schemat konstrukcji uwzględnionej w obliczeniach stanów granicznych,

Fig. 9 Sections of frame elements.

Rys. 9 Przekroje elementów ramy

Fig. 10 The frame joint details: a) beam-to-column joint, b) truss bracing-to-column connection

Rys. 10 Szczegóły połączeń ramy: a) węzeł belka-słup, b) połączenie stężenia kratowego ze słupem

Fig. 11. Graphical illustration of the degree of stiffness reduction of frame elements: a) load combination COMB GQS, b) load combination COMB GS , c) load combination COMB GWQS 
Rys. 11 Ilustracja graficzna stopnia degradacji sztywności elementów ramy: a) kombinacja obciążeń COMB GQS, b) kombinacja obciążeń COMB GS, c) kombinacja obciążeń COMB GWQS

Fig. 12. Load multiplier and stiffness degradation vs. dimensionless vertical displacement characteristics for COMB GQS

Rys. 12 Charakterystyki mnożnika obciążenia i degradacji sztywności w funkcji bezwymiarowego przemieszczenia pionowego

Fig. 13. Load multiplier and stiffness degradation vs. dimensionless horizontal displacement characteristics for COMB GWQS

Rys. 13 Charakterystyki mnożnika obciążenia i degradacji sztywności w funkcji bezwymiarowego przemieszczenia poziomego

Fig. 14 Reinforced frame elements: a) beams, b) columns, c) bracing bars

Rys. 14 Wzmocnione elementy ramy: a) belki, b) słupy, c) stężenia

Fig. 15 Load multiplier and stiffness degradation vs. vertical displacement relationships for COMB GQS

Rys. 15 Charakterystyki mnożnika obciążenia i degradacji sztywności w funkcji bezwymiarowego przemieszczenia pionowego dla COMB GQS

Fig. 16 Load multiplier and stiffness degradation vs. horizontal displacement relationships for COMB GWQS

Rys. 16 Charakterystyki mnożnika obciążenia i degradacji sztywności w funkcji bezwymiarowego przemieszczenia poziomego dla COMB GWQS

Fig. 17 The modified beam-to-column joint detail of Frame B

Rys. 17 Szczegół zmodyfikowanego połączenia belki ze słupem w ramie B

Fig. 18 Load multiplier and stiffness degradation vs. vertical displacement relationships

Rys. 18 Mnożnik obciążenia i degradacja sztywności w funkcji bezwymiarowego przemieszczenia pionowego

Fig. 19 Load multiplier and stiffness degradation vs. horizontal displacement relationships

Rys. 19 Mnożnik obciążenia i degradacja sztywności w funkcji bezwymiarowego przemieszczenia poziomego

Table 1. Load combinations

Tablica 1 Kombinacje obciążeń

Table 2. Load multipliers and verification criteria for original frame - Frame A-CS1

Tablica 2 Współczynniki obciążeń i kryteria weryfikacji oryginalnej ramy - Rama A-CS1

Table 3. Load multipliers and verification criteria for modified frame - Frame A-CS2

Tablica 3 Współczynniki obciążeń i kryteria weryfikacji zmodyfikowanej ramy - Rama A CS2

Table 4. Stiffness and strengths of semi-continuous joints

Tablica 4 Sztywności i nośności węzłów podatnych 
Table 5. Load multipliers and verification criteria for semi-continuous frame

Tablica 5 Współczynniki obciążeń i kryteria weryfikacji ramy z węzłami o niepełnej ciągłości

Table 6. Load multipliers and verification criteria for rigid frame

Tablica 6 Współczynniki obciążeń i kryteria weryfikacji ramy z węzłami sztywnymi 


\title{
DIRECT DESIGN AND ASSESSMENT OF THE LIMIT STATES OF STEEL PLANAR FRAMEWORKS USING CSD ADVANCED ANALYSIS
}

\begin{abstract}
Keywords: steel framework, I-section member, class 1 section, braced frame, in-plane CSD advanced analysis, direct design, direct assessment of existing framework
\end{abstract}

\section{SUMMARY:}

This paper is entirely devoted to practical aspects of direct design and assessment of safety and serviceability of steel planar framework using advanced analysis. The development of advanced analysis has been driven by a desire for a more accurate representation of the behaviour of planar framework by considering the beam and spring numerical modelling technique together with plasticity and geometrically nonlinear effects as well as structural imperfections accounted for. The validated 2D version of CSD advanced analysis developed by the author is used in this paper for its practical application towards the resistance and serviceability assessment of existing simple construction framework. This steel braced frame was a subject of technical expertise. The same structure geometry but with different joint detailing is then considered to show how the effect of joint properties may affect the braced frame performance. Results of investigations are presented in the form of frame global response at both the ultimate limit state and the serviceability limit state, and also in the form of member local responses. Conclusions with regard to general design and assessment practice are drawn. 


\title{
BEZPOŚREDNIE PROJEKTOWANIE I OCENA STANÓW GRANICZNYCH STALOWYCH RAM PLASKICH NA PODSTAWIE ZAAWANSOWANEJ ANALIZY CSD
}

\author{
Slowa kluczowe: rama stalowa, I-przekrój elementu, ramy stężone, zaawansowana analiza CSD, projektowanie \\ bezpośrednie, bezpośrednia ocena istniejącej ramy
}

\section{STRESZCZENIE}

Artykuł dotyczy projektowania z wykorzystaniem analizy zaawansowanej. Przedstawiono krótki przegląd aktualnego stanu badań w tym zakresie i wkład autora w rozwój bezpośredniego projektowania i oceny konstrukcji stalowych przy użyciu zaawansowanej analizy CSD, która jest najbardziej zbliżona do rzeczywistego zachowania się stalowych szkieletowych systemów nośnych.

Zaproponowano schemat oceny projektu przy użyciu analizy CSD dla układów płaskich, uwzględniający możliwość oceny stanów granicznych nośności i użytkowania w jednym przebiegu analizy.

Do zaprezentowania różnic w modelowaniem struktury za pomocą zaawansowanej metody klasycznego udoskonalonego przegubu plastycznego (RPH) i proponowanej metody ciągłej degradacji sztywności (CSD) wykorzystano kratownicę Misesa wrażliwą na wyboczenie sprężyste. Przykład pokazuje różnice między obu podejściami analitycznymi w przypadku, gdy elementy kratownicy są wykonane z kątowników połączonych z konstrukcją za pomocą spoin lub śrub. Główny cel tego artykułu, ocenę projektu przy użyciu analizy CSD, zilustrowano praktycznym zastosowaniem zaproponowanego schematu oceny w szczegółowych badaniach stanów granicznych nośności i użytkowalności (ULS i SLS) prostej konstrukcji o schemacie ramy stężonej. Konstrukcja ta była przedmiotem ekspertyzy technicznej wykonywanej w Politechnice Warszawskiej w odniesieniu do wersji pierwotnie zbudowanej, a także wersji zmodyfikowanej, uwzględniającej wzmocnienie części elementów. Zbadano stan pierwotnie zaprojektowanej ramy, dokonując oceny ULS i SLS w zgodnie z proponowanym algorytmem. Przedstawiono wyniki obliczeń ramy, a następnie skutki wzmocnień jej elementów i porównano obie sytuacje projektowe. Następnie rozważono tę samą geometrię ramy, ale z uwzględnieniem półsztywnych i nominalnie sztywnych połączeń rygli ze słupami. Porównano stopnie wykorzystania kryteriów stanów granicznych i wpływ degradacji sztywności elementów na ich wartości. Ukazano przydatność prezentowanego podejścia w ocenie stanu istniejącego i projektowaniu ramowych konstrukcji stalowych. 